https://oi.org/10.19195/0080-3626.63.4

LARYSA DOǓNAR

\title{
БЕЛОРУССКАЯ КНИГА И НАУКА О КНИГЕ: ФОРМИРОВАНИЕ ПОНЯТИЙ, НАУЧНЫХ ПАРАДИГМ И АВТОНОМНОЙ НАУЧНОЙ ДИСЦИПЛИНЫ
}

Początki myśli bibliologicznej na Białorusi w związku z pojawieniem się i rozwojem tamtejszego piśmiennictwa. Kształtowanie się na Białorusi księgoznawstwa jako nauki od przełomu XVIII/XIX wieku. Ścisłe jego związki z bibliografią, historią i filologią oraz działalnością naukową uczonych polskich, rosyjskich i litewskich. Powstanie i rozwój właściwej białoruskiej nauki o książce w związku z kształtowaniem się tożsamości narodowej Białorusinów od 1918/1919 roku. Położenie podwalin pod rozwój podstawowych zasad teoretycznych i metodologicznych w badaniach nad kulturą książki. Powstanie instytucji publicznych zajmujących się problematyka bibliologiczną. Autonomia białoruskiej nauki o książce w stosunku do szkół księgoznawczych rosyjskiej, polskiej i ukraińskiej. Zintegrowany charakter problematyki kultury książki na Białorusi, włączenie problematyki badawczej i metodologii księgoznawstwa do innych dyscyplin naukowych (szczególnie historii i historii literatury). Współczesne czasopisma księgoznawcze i specjalistyczne księgoznawcze serie wydawnicze oraz ich rola w rozwoju białoruskiej nauki o książce.

SŁOWA KLUCZOWE: bibliologia (księgoznawstwo, nauka o książce), historia bibliologii, historia bibliologii białoruskej, historia białoruskiej książki, białoruska kultura książki, Białoruś

Зарождение книговедческой мысли в Беларуси в связи с появлением и развитием местной литературы. Формирование книговедения в Беларуси как науки на рубеже XVIII-XIX веков. Тесные его связи с библиографией, историей и филологией, а также с научной деятельностью польских, российских, литовских учёных. Возникновение и развитие собственно белорусской науки о книге в связи с формированием национальной идентичности белорусов в 1918-1919 гг. Заложение основ для разработки фундаментальных теоретических и методологических принципов в изучении книжной культуры. Создание государственных учреждений, занимающихся книговедческими вопросами. Автономия белорусской науки о книге по отношению к русской, польской и украинской школам книговедения. Интегрированный характер вопросов книжной культуры в Беларуси, включение проблемы исследования и методологии изучения книг в другие научные дисциплины (в частности в историю и историю литературы). Современные книговедческие журналы и специализированные книговедческие серии и их роль в развитии белорусской науки о книге.

КЛЮЧЕВЫЕ СЛОВА: книговедение, история книговедения, история белорусского книговедения, история белорусской книги, белорусская книжная культура, Беларусь

ROCZNIKI BIBLIOTECZNE ROCZNIKI BIBLIOTECZNE, R. LXIII: 2019

ROK LXIII, 2019

(C) for this edition by CNS 
Историзм книговедческих знаний и исследований, история зарождения и становления книговедения, или в целом история книговедения как науки не только в определенной стране ${ }^{1}$, регионе $^{2}$, но и в мире ${ }^{3}$, как особое направление книговедческих исследований является одной из актуальных проблем современности, подтверждаемой авторитетными учеными разных стран. Понимание подобных подходов характерно и белорусским исследователям ${ }^{4}$, для которых особенно важным в вопросах осознания белорусской науки о книге являются вопросы выявления собственного и собственно книговедческого опыта.

Как можно заметить, ряд вопросов, связанных не только с историей белорусской книги, но и ее теоретическим обоснованием (и идентификацией), традиционно наиболее активно подвергался рефлексии в юбилейные годы белорусского книгопечатания, когда и было издано ряд основательных трудов. Так произошло в 1920-е годы, когда впервые отмечалось 400-летие со

${ }^{1}$ Например: К. Мигонь, История книговедения как наука (замечания по материалам польских исследований), [в:] Федоровские чтения, 2011, Москва 2012, с. 215-227; И. А. Шомракова, Д. А. Эльяшевич, Отечественное книговедение в XXI в.: проблемы и перспективы, „Библиосфера” 2012, № 3, с. 9-12; Buchwissenschaft in Deutschland: Ein Handbuch, ред. U. Rautenberg, Berlin-New York 2010, т. 1-2; Г. Ковальчук, Розвиток теорії книгознавства на сучасному етапі, „Бібліотечний вісник” 2009, № 5, с. 44-53; Н. К. Леликова, Наука о книге в России, или К вопросу о методологии исторических исследований, [в:] Книга. Исследования и материаль, Москва 2007, сб. 86/1, с. 67-103; eadem, Становление и развитие книговедческой и библиографической наук в России в XIX-первой трети XX века, Санкт-Петербург 2004.

${ }^{2}$ Например: K. Migoń, Особенности восточноевропейского книговедения и формирование национальных научных школ до Второй мировой войны, „Knygotyra” 2007, т. 48, c. 9-21; М. В. Шабалина, Книговедение: опыт региональных изысканий, [в:] Библиотекарь и время. ХХІ век, Мосва 2006, вып. 50.

${ }^{3}$ К. Мигонь, Историография науки о книге: концептуальные парадигмы, „Библиография". 2017, № 5, с. 5-18; idem, О необходимости и пользе исследований по истории науки о книге: опыт науковедческого анализа, „Knygotyra” 2013, т. 60, с. 19-32; А. А. Беловицкая, Книговедение. Общее книговедение, Москва 2007.

${ }^{4}$ Например: В. М. Герасімау, Кнігазнаўства, [в:] Эниыклапедыя гісторыі Беларусі: y 6 m., т. 4, гал. рэд. Г. П. Пашкоў, Мінск 1997, с. 213-214; Л. И. Довнар, Книговедческое знание и белорусская библиография: источники и ориентиры, [в:] Труды Международного библиографического конгресса (Санкт-Петербург, 21-23 сентября 2010 г.), ч. 3, Санкт-Петербург 2012, с. 238-248; eadem, Возникновение и развитие науки о книге в Беларуси: истоки и перспективы книжной культуры во взаимосвязи, [в:] Федоровские чтения, 2011, Москва 2012, с. 250-265; eadem, Белорусское книговедение и национальное возрождение 1920-х годов, „Knygotyra” 2007, т. 48, с. 53-66; Ю. Лаўрык, Гістарычнае кнігазнаўства як самастойная навука: да пастанойкі праблемы Беларуская кніга ў кантэксие сусветнай кніжнай культуры, Мінск 2014, вып. 5, с. 34-43.

ROCZNIKI BIBLIOTECZNE

ROK LXIII, 2019

(C) for this edition by CNS 
дня издания Апостола 5 (Вильня, 1525) ${ }^{6}$, а в 1960-е годы - 450-летие начала издания Библии руской (Прага, 1517) Франциска Скорины ${ }^{7}$, и далее - до особенно значительной даты в 2017 году - 500-летия белорусского книгоиздания, когда было заявлено о том, что в Беларуси наконец-то разрешены важнейшие теоретические вопросы, связанные с идентификацией „национального документа” и „белорусской печати”:

К наследию белорусской книжной культуры начали относить целые пласты литературы, которую раньше рассматривали как зарубежную, например, польскоязычные и другие издания. Завершился на теоретическом уровне очень сложный процесс идентификации белорусской печати на протяжении ее существования как явления мультиэтничного, многоязычного и разношрифтового. Новые подходы существенно расширили круг национальных авторов и документов ${ }^{8}$.

Компромиссному решению теоретических вопросов „установления своих" идентификационных маркеров содействует и такая перспективная исследовательская категория как транскультурная стратегия 9 , особенно значимая в сфере общего культурного и научного наследия разных народов. Одновременно исследование зарождения и развития научной мысли (особенно в гуманитарной сфере) имеет междисциплинарный характер или общие корни, основанные на слове, текстах, закрепленных в известных первоисточниках: в рукописных и печатных книгах, в которых и белорусские ученые открывают истоки своих научных знаний.

Истоки книговедческой мысли, как справедливо отмечают и белорусские исследователи ${ }^{10}$, были тесно связаны с появлением и распространением книг - христианской письменности (не позже XI века, которым датируются

5 Одним из первых, кто выссказал идею отметить в 1925 г. 400-летие белорусского книгопечатания, был Вацлав Ластовский, предложивший — на страницах издаваемого им в Ковне журнала „Крывіч” - для юбілейной даты взять за отсчет год издания Франциском Скориной книги Апостал на территории ВКЛ в Вильне в 1525 г.

6 В. Ластоўскі, Гісторыя беларускай (крыўскай) кнігі: Спроба паясьніцельнай кнігопісі ад каниа X да пачатку XIX стагодзьдзя, Коўна 1926 (Друк. Сакалоўскага і Лана); Чатырохсотлеице беларускага друку: 1525-1925, Менск 1926.

7450 год беларускага кнігадрукавання, Мінск 1968; А. И. Журавский, А. Н. Булыко, 450 лет белорусского книгопечатания, [в:] Книга. Исследования и материаль, Москва 1967, сб. 14.

8 Т. В. Кузьмініч, А. В. Іванова, Нацьяянальная бібліяграфія $i$ захаванне кніжнай спадчыны Беларусі, [в:] Матэрыялы міжнароднага кангрэса „500 гадоў беларускага кнігадрукавання". ХІІІ Міжнародныя кнігазнаўчыя чытанні (Мінск, 14-15 верасня 2017 г.): у 2 ч., Мінск 2017, ч. 1, с. 23.

9 В. М. Дианова, Транскультурация как стратегия изучения культурного наследия: белорусские ландшафты, [в:] Першы міжнародны кангрэс беларускай культуры (Мінск, 5-6 мая 2016 г.), гал. рэд. А. І. Лакотка, Мінск 2016, с. 29.

10 В. М. Герасімаў, Кнігазнаўства, [в:] Энцыклапедыя гісторыі Беларусі: у 6 m., т. 4, гал. рэд. Г. П. Пашко, Мінск 1997, с. 213; Л. И. Довнар, Книговедческое знание и белорусская библиография: источники и ориентиры..., с. 238. 
первые отечественные рукописные книги). Известно, что восточные славяне вкладывали в понятие книга не столько умение писать, сколько знания вообще, считая книгу высшей ценностью. На протяжении многих веков складывались определенные правила (знания) создания книг - написания, переписки, оформления, чтения, придававшие слову сакральный, Божественный смысл; книга воспринималась как Божественное писание, откровение ${ }^{11}$. Нередко тексты книг содержали и первые библиографические сведения: назидательные, т. е. рекомендательные; авторитетные, т. е. включающие ссылки на другие источники; запретные, т. е. цензурные. Слово книжное было и словом о книгах, что отражали проповеди, слова, поучения Ефросиньи Полоцкой, Кирилла Туровского, Климента Смолятича, Аврамия Смоленского.

Научиться читать значило в то время научиться владеть инструментом для понимания и знания священных текстов и их бесконечных комментариев, в том числе на письме ${ }^{12}$. Книжные, а значит настоящие знания считались необходимым условием набожности, правоверности и самого звания христинина, который должен был читать книги (святые), а не „книги” ложные или отреченные. Однако и их, независимо от того, что запрещали и утрачивали, всё же читали - знали (!), хотя бы для того, чтобы, как Кирилл Туровский, назвать их ненастоящими, не имевшими Божественной мудрости (Слово святого Кирилла о книжном почитании и о учении, XII в.). Прочные средневековые основы книжности — канонические книжные знания, обладающие наивысшей Божественной ценностью, заложенные, возможно, ещё апостолами $^{13}$, нерушимо существовали почти до начала возникновения книгопечатания, служили универсальной методологией учености.

Потребность в знании о книгах нашла отражение в описях, инвентарях, каталогах церковных, монастырских и частных библиотек (напр., наиболее ранние описи из сохраненных - Опись Слуц̧кого Троицикого монастыря архимандрита Иосифа, [...] 1494 г. ${ }^{14}$, Опись Супрасльского монастыря, составленная игуменом Сергием Кимбаром, 1557 г. $^{15}$ ); в поучительных сбор-

11 Из рукописи Программы лекиции В. Ластовского по „Истории книги” (Саратов 1936) - см.: Из бумаг В. У. Ластовского, подготовка и публикация текста Н. А. Попковой, Беларуская кніга ў кантэксие сусветнай кніжнай культуры, Мінск 2011, вып. 3, с. 196-198.

12 Л. В. Левшун, Очерки истории средневековой восточнославянской книжности: эволючия творческих методов, Минск 2000, с. 5-7.

13 Ibidem, c. 7.

14 Акты, относящиеся к истории Западной России, собранные и изданные Археографической комиссией, Санкт-Петербург 1846, т. 1, с. 136-137, № 115.

15 Документы относящиеся к истории Супрасльского монастыря, „Вестник Западной России", кн. 8, т. 3, отд. 1, Вильно 1867, с. 49-62; Археографический сборник документов, относящихся к истории Северо-Западной Руси, издаваемый при управлении Виленского учебного округа, т. 9, Вильно, 1870, с. 49-55; Wstęp, [в:] Rękopisy supraskie w zbiorach krajowych i obcych, oprac. A. Marcinowicz; Katalog rękopisów supraskich, oprac. A. Mironowicz, N. Morozowa, M. Czistiakowa et al., Białystok, 2014, c. 8; A. Kaszlej, [rec.] Rękopisy supraskie

ROCZNIKI BIBLIOTECZNE

ROK LXIII, 2019

(C) for this edition by CNS 
никах - Измарагд первой четверти XVI в. из Супрасльского монастыря (с записью книжника Ивана Проскуры 1593 г.) ${ }^{16}$, в котором на 243-246 листах был помещен раздел $О$ книгах ихъ же подобаетъ чести и внимати, ихъ же не внимати, ни чести, представляющий довольно полную характеристику репертуара книжности XVI в.

Самыми ранними белорусскими печатными источниками, даносящими свидетельства о некоторых изменениях в развитии знаний о книге и дальнейшем формировании книговедческой мысли в эпоху Возрождения ${ }^{17}$, являются пражские и виленские издания Франциска Скорины ${ }^{18}$, предисловия к которым представляют не только своеобразную авторскую апологию книге и чтению (просвещению, науке, мудрости „постижения самого себя”), но и одну из форм проявления критической мысли. Объединенные общим программно-просветительским подходом автора, они содержат и теоретико-концептуальные книговедческие рефлексии, в числе которых распознаются будущие научные категории - это миссия и философия книги, духовные и моральные составляющие книги, функциональное назначение книги и чтения, книга и язык, форма и содержание книги, книговедческая лексика, автор-книга-читатель и др. Среди общих вопросов обращает на себя внимание методология и подходы Ф. Скорины к изучению истории печатаемых им книг, которые основывались, с одной стороны, на традиции Средневековья - приводить основные положения, мысли, опираясь на библейские тексты, первоисточники, и их объяснения наиболее авторитетными авторами, а также, с другой стороны - предлагались собственно авторские гуманистические взгляды, акцентированные на вопросах и морально-этических аспектах текстов, их роли в просвещении и приобретении практических знаний ${ }^{19}$, под которые подводилась и нациосозидающая основа, и понимание разнообразия и единства мира.

Франциск Скорина, не деливший знания (книги) на истинные и ложные, в качестве универсальных знаний рекомендовал Библию, именно в ней он

w zbiorach krajowych i obcych..., ,, Roczniki Biblioteki Narodowej, c. 275-280, https://bn.org.pl/ download/document/1439460924.pdf [дата доступа: 22.12.2019].

16 Н. А. Морозова, С. Ю. Темчин, Древнейшие рукописи Супрасльского Благовещенского монастыря (1500-1532), [в:] Z dziejów monasteru Supraskiego: materiały międzynarodowej konferencji naukowej.., Supraśl-Białystok, 10-11 czerwca 2005 r., Białystok 2005, c. 117-140.

17 Л. І. Доўнар, Кнігазнаўчая думка у эпоху Францыскка Скарыны: інтэрпрэтацылі паводле кнігі „Iисипda familia librorum. Humaniści renesansowi w świecie ksiażki” Януша С. Грухалы, [в:] Беларуская кніга ў кантэксие сусветнай кніжнай культуры, Мінск 2017, вып. 7, с. 134-151.

18 Л. І. Доўнар, Францыск Скарына і вытокі кнігазнаўчых ведаў Беларусі, [в:] Франииск Скорина - личность, деятельность, наследие, современные образы, сост. Л. А. Авгуль, Д. Н. Бакун, Минск-Москва 2017, с. 46-53.

19 В. Н. Дышыневіч, Першакрыніцы у уы выданнях Ф. Скарыны, [в:] Франиыск Скарына і яго час: энцыклапедычны даведнік, ред. І. П. Шамякін et al., Мінск 1988, с. 447-448.

ROCZNIKI BIBLIOTECZNE

ROK LXIII, 2019

(C) for this edition by CNS 
видел духовное спасение. В одном из послесловий Ф. Скорина называет себя учителем „в науках и в лекарстве”20. В ряде других предисловий Ф. Скорина показывает почтительное отношение к авторам - наставникам, которых он наследует $^{21}$. Книги и книжницы (библиотеки) понимаются им как наивысшие ценности, сохраняющие и продолжающие человеческую память ${ }^{22}$. Чтению книг Библии, как в целом чтению, Ф. Скорина уделяет очень пристальное внимание, применяя системно-диференцированный подход: ${ }^{23}$ „Пожиточьны же суть сие книгы чести всякому человьку, мудрому и безумному, богатому и вбогому, младому и старому, набольй тым, они же хотять имети добрые обычае и познати мудрость и науку” 24 . Ведь „всяко писание Богом водъхненое полъезно ест ко учению и ко обличению, исправльнию, и ко наказанию правды. Да совършен будеть человък божий и на всяко дъло добро уготован" 25 .

Таким образом, и книга, и автор становятся духовными наставниками человека (читателя), о чем также свидетельствуют предисловия-,трактаты” ряда известных гуманистов-книжников, таких как Сымон Будный, Матвей Ковечинский, Лаврентий Кришковский, Василь Тяпинский, Иван Фёдоров, Пётр Мстиславец, Григорий Хадкевич, Константин Острожский, Леон Мамонич, Иаиль Труцевич, Симеон Полоцкий и др. В их морально-эстетических и идейных программах ${ }^{26}$ особое значение придается книге и слову на родном языке, в том числе и через комментарии, объяснения, переводы с греческого, латинского и еврейского языков. Значение книги в интеллектуальной деятельности, результатом которой становилось само издание книги, было непреходяще: ведь книга - это „сосуд Христов”, „овоц працы”, „оружіе духовное”, „наяснъйшая походня” - общий духовный источник, утверждающий содру-

20 Ф. Скарына, Прадмовы і пасляслоўі, сост. А. Ф. Коршунаў, Мінск 1969, с. 116.

21 Например: „Книгу сию, рекомую Премудрость, написал ест Филон Философ греческим языком, яко о том кажеть святый Герасим в предмолъвъ своей” - см.: Предословие доктора Франъииска Скорины в Книгу Премудрости Божией, [в:] Ф. Скарына, Прадмовы i nасляслоўі..., с. 34; „Феодосий же, учитель великий греческаго языка, выложил с хальдейскаго писма на греческое, и светый Ероним - на латинское зуполне" — см.: Предословие доктора Франъииска Скорины с Полоцъка в Книги Даниила-пророка, [в:] Ф. Скарына, Прадмовы і пасляслоўі..., с. 105; „Исус Сирахов - он же написал ест книгу сию еврейскым языком и потом из еврейскаго языка преложил ест на греческый язык на прозбу Птоломея Евереета, царя Египетскаго”- см.: Починается другая Предъмолъва доктора Франъииска Скорины в Книгу Исуса Сирахова, [в:] Ф. Скарына, Прадмовы і пасляслоўі..., с. 22.

22 Починается другая Предъмольва доктора Франъичска Скорины в Книгу Исуса Сирахова, [в:] Ф. Скарына, Прадмовы і пасляслоўі..., с. 22-24.

23 Ibidem, c. 24.

24 Предсловие в Притчи премудраго Саломона, иаря Израилева, [в:] Ф. Скарына, Прадмовы і пасляслоўі..., с. 20.

25 Предъсловие в Псалтирь, [в:] Ф. Скарына, Прадмовы і пасляслоўі..., с. 9-11.

26 У. Г. Кароткі, Тыпалогія прадмоў і пасляслоўяў беларускіх паслядоўнікаў Скарыны, [в:] Спадчына Скарыны: зборнікматэрыялаў Першых Скарынаўскіх чытанняў (1986), уклад. А. І. Мальдзіс, Мінск 1989, с. 231.

ROCZNIKI BIBLIOTECZNE

ROK LXIII, 2019

(C) for this edition by CNS 
жество „отчизны духовной и свецкой”27. В предисловиях не только делались попытки объяснить ценность книги: „Сія убо, нарицаемая Псалтырь, подобна суть великому морю, от моря бо не оскудъвает вода николи же, ни умаляется изливанием рък і источник. Тако и от Псалтырі не оскудъвает пъніе никогда же" 28 , книга провозглашалась неотъемлемой частью духовной жизни человека, ведь она нужна ,господареви и челядникови дома, ремесникови на варстатъ, крамареви при крамъ, купцу и пелкгримови в дорозъ. Жолнерови в тягненію и на войнъ, жеглярови на водъ, мнихови в целли, а священникови дома и в церкви" 29 . В целом можем говорить, что во всём комплексе предисловий и послесловий к изданиям ряда белорусских первопечатников и просветителей XVI-XVII вв., которые собственно могут представлять и своеобразные формы трактатов ${ }^{30}$, мы находим истоки знаний о книге: о ее значении и предназначении, понимании и толковании, миссии и функциях.

Глубоко продуманное понимание роли чтения и книги в процессе творения человека набожного и просвещенного демонстрирует белорусский просветитель Симеон Полоцкий (Самуил Гаврилович Петровский-Ситнианович, 1629-1680) ${ }^{31}$, которому характерно стремление к обобщению книжной мудрости разных народов (белорусов, украинцев, поляков) и как можно широкому ее распространению, в том числе реализации на практическом уровне просветительской программы, которая приобрела общегосударственное значение и содействовала коренным сдвигам в российском образовании ${ }^{32}$. Свои взгляды относительно книг и чтения Симеон Полоцкий высказал не только в предисловиях к читателям в напечатнных изданиях, но и в специально сочиненных стихах ${ }^{33}$. Его заслуга и в том, что он «первый на русской почве писал на „книжные” темы в стихах. <..> Главное — то, что „книга”, „чтение”, „мудрость”, „философия” и прочее является для Симеона средством просвещения человека» ${ }^{34}$. Стихи Симеона Полоцкого стали не

27 У. Г. Кароткі, Беларускія прадмовы і пасляслоўі другой палавіны XVI-XVII cm., [в:] Прадмовы і пасляслоўі Франщыска Скарыны, Мінск 1991, с. 19.

28 Цит. по: У. Г. Кароткі, Беларускія прадмовы і пасляслоўі другой палавіны XVIХVII ст..., с. 19: Псалмы... Вильна 1593. Л. 10 адв.

29 Цит. по: У. Г. Кароткі, Беларускія прадмовы і пасляслоўі другой палавіны XVIXVII cm..., с. 19. Польустав, или Требник... Вільна, 1622. Л. 2 адв. другога ліку.

30 У. Г. Кароткі, Беларускія прадмовы і пасляслоўі другой палавіны XVI-XVII ст..., с. 8.

31 Г. Я. Голенченко, Белорусы в русском книгопечатании, [в:] Книга. Исследования и материалы, Москва 1978, сб. 13, с. 110-111.

32 Гісторыя беларускай літаратуры XI-XIX стагоддзяў: у 2 m., рэд. В. А. Чамярыцкі, т. 1, Даўняя літаратура, XI-першая палова ХVIII стагоддзя, Мінск 2006, с. 680.

33 См.: Из истории философской и общественно-политической мысли Белоруссии. Избранные произведения XVI-начала XIX в., ред. В. М. Пузиков, Минск 1962.

34 П. Н. Берков, Книга в поэзии Симеона Полоикого, [в:] Литература и общественная мысль Древней Руси: к 80-летию со дня рождения члена-корреспондента АН СССР В. П. Адриановой-Перети, Ленинград 1969, т. 24, с. 260. 
только похвалой книге, характерной европейским просветителям, но и отражением ее просветительской миссии.

B XVII-XVIII вв. с расширением репертуара светской, научной тематики знания о книге становятся необходимым условием в издательской, библиографической, библиотечной и книготорговой деятельности. Они проявляются при описании и систематизации разнообразных книжных собраний, при включении библиографической информации на страницы зарождающейся периодической печати. Делаются первые попытки изучения книжного наследия в контексте истории края, его книжных традиций, в просвещении народа книга приобретает важнейшее значение. Влияние идей европейского Просвещения отражается в результатах деятельности Ильи Копиевича, Иоахима Хрептовиач, Игнатия Быковского, Яна Снядецкого, Михаила Бобровского, Игнатия Даниловича и др., участвовавших в том или ином процессе книжного дела. Нельзя не напомнить о уроженце Беларуси Илье Копиевиче (Илья Фёдорович Копиевский $)^{35}$, зачинателе гражданской азбуки, который „учитывая европейский опыт, издал на латинском и русском языках первые варианты печатных библиографических пособий”з6. Убежденно писал И. Копиевич о необходимости знаний, заключенных в книгах, пользе познания письменности, к примеру, в Кратком собрании Льва Миротворияа ${ }^{37}$ :

35 Илья Копиевич окончил Слуцкую протестантскую гимназию, владел несколькими иностранными языками, принимал участие в разработке гражданского шрифта в петровской России (используя для основы шрифт Ф. Скорины). Переводчик и издатель ранних русскоязычных научных трудов в Амстердаме (с 1699 по 1706 г.). Он составил на русском и латинском языках первые учётно-регистрационные или издательские формы библиографических пособий (реестров), предназначенные для Петра I: в 1699 г. — „Рядовой чин, имъ же книги именуются въ 17 месяцахъ списаны, сиречь наченши лета от р. х. 1698 даже до нынешняго дня совершаемы аутором Elia Федоровымъ Копиевскимъ, си есть. отъ копии Копиевскимъ, яже по указу пресветлейшаго и великаго государя въ Амстердаме писаль и в друкъ, или печать издаль” реестра); в 1700 г. — „Рядовый чин им же книги именуются писаны и изданы автором. Елиа Федоровым Копиевским”, помещенный в издании Latina grammatica (Латинская грамматика) (Амстердам, 1700), в 1706 г. — „Index exhibens libros in lingua russica, seumoscovitica scriptos auctore Elia Copijewitz, alias de Hasta Нastenio", приложенный к книге Руковедение в грамматыку. Во славянороссийскую (Штольценберг, 1706), в 1710 г. — „Реестр книгам гражданским, которые по указу царского величества напечатаны новоизобретенною амстердамскою азбукою по первое число июня нынешнего 1710-го году”, напечатанный в приложении к газете „Ведомости” (№ 12).

36 А. А. Гречихин, Глава 6. Развитие русской библиографии в XVIII в., 6.1. Первые русские печатные библиографические пособия, [в:] idem, Общая библиография, Москва 2000 , www.hi-edu.ru/e-books/cb/index.htm; см. также: А. М. Чеботарев, $K$ вопросу об уточнении первого этапа развития рекламы книги в России в XVIII веке, „Вестник Казанского государственного университета культуры и искусств" 2012, https://cyberleninka.ru/article/n/k-voprosuob-utochnenii-pervogo-etapa-razvitiya-reklamy-knigi-v-rossii-v-xviii-veke; Z. Nowak, Kopijewicz Eliasz, [в:] Słownik pracowników książki polskiej, Warszawa-Łódź 1972, с. 437; Н. Ю. Бярозкіна, Гісторыя кнігадрукавання Беларусі (XVI-пачатак XX cm.), Мінск 2000, с. 76.

37 Из истории философской и общественно-политической мысли Белоруссии..., с. 324.

ROCZNIKI BIBLIOTECZNE

ROK LXIII, 2019

(C) for this edition by CNS 
Ничто же полезнейшее есть в сем житии, как познание и умелость письмен. Сие приношает величество и славу, сие неизреченную красоту воздает, сие государства великия укрепляет и расширяет, и прославляет - всякому человеку во всяком чину полезно. Письмена разум исправляют и обучают, и утешают, откуда храбрость и добродетели в первоначальниках з научения и чтения письмен. Не токмо бо красотою и славою возвелисиваются, но цвет точию имеющий величества своего от письмен покров, благородие и силу: ими же своим любезнейши суть, супостатом же - страшнейший ${ }^{38}$.

В целом же можно сказать, что духовная жизнь, так же как и книжные знания Беларуси, в XVI-XVIII вв. развивались в русле гуманистического наследия Ф. Скорины, основываясь на самоценности личности и гражданина, компромисно сосуществуя в поликультурном сообществе, распространяя и преумножая европейский опыт, сохраняя собственные традиции. „Новое книжное знание" зижделось на непременном опыте предыдущего, о чем и свидетельствовали, к примеру, ссылки на книги, их цитирование и характеристика, роль которых заключалась не только в исполнении функции представления текста, но также и в соблюдении уже сложившейся „книжной традиции", выработавшей свои законы, принципы и даже функции книги относительно читателя и читателя относительно книги ${ }^{39}$. Таким образом, истоки книговедческого знания выявлются как в составе комплекса универсальных знаний (теологических, исторических, философских, филологических, педагогических, просветительских), так и сами составляют общую гуманистическую книжно-знаниевую (книговедческую) парадигму.

Богатое книжное наследие, разнообразие научных трудов создали в конце XVIII-начале XIX в. необходимые предпосылки для формирования и теоретических основ новой науки или наук о книге и в Виленском университете $^{40}$, интеллектуальном центре Литвы и Беларуси. Огромное влияние на общую идейную атмосферу в университете имел историк Иоахим Лелевель ${ }^{41}$. Его работы, написанные в эпоху изменений социальных и политических идей, общественной ментальности, свидетельствовали о формировании как интереса к истории книги, так и о развитии науки о книге,

38 Цит. по кн.: П. Пекарский, Наука и литература в России при Петре Великом, СанктПетербург, 1862, т. 1, с. 22.

39 См.: Л. І. Доўнар, Кнігазнаўчая думка ў эпоху Францыьска Скарыны: інтэрпрэтаиыі паводле кнігі „Iисипda familia librorum. Humaniści renesansowi w świecie książi” Януша С. Грухалью.., с. 134-151.

40 А. Навицкене, Формирование наук о книге и Вильнюсский университет в первой трети ХІХ века, [в:] Беларуская кніга у кантэксие сусветнай кніжнай культуры, Мінск 2017, вып. 7, с. 52-74.

41 Д. Караў, В. Семенякоў, Лялевель (Lelewel) Iaaxiм, [в:] Энцыклапедыя гісторыі Беларусі: y 6 m., т. 4, гал. рэд. Г. П. Пашкоў, Мінск 1997, с. 423-424; Л. І. Доўнар, Кнігазнаўчыля веды для бібліятэкараў ад Iаахіма Лялевеля, [в:] Матэрыялы XIV Між-народных кнігазнаўчых чытанняй, прымеркаваных да 400-годдзя першага „Буквара”, Мінск, 26-27 красавіка 2018 г., уклад. Т. А. Сапега, А. А. Суша, Мінск 2018, с. 250-255. 
называемой библиографией, а также о необходимости историографических и теоретических обобщений в данной области. В работе Что такое библиогpaфия (Co jest bibliografia?, 1826) ${ }^{42}$ И. Лелевель выделил, как и западные теоретики того времени М. Денис, Э. Г. Пеньо, науку о печатной книге („,типография”), науку о рукописях (,графика”), науку о библиотечной книге („библиотечное дело”); в Истории Литвы и Руси аж до Люблинской унии с Польшей 1569 г. (Dzieje Litwy i Rusi aż do unii z Polska w Lublinie, 1839) писал о восточно-славянской культуре, значении „статутного” языка в Великом Княжестве Литовском и деятельности Франциска Скорины, Мамоничей, Заблудовской типографии и др.

Последователем И. Лелевеля являлся и уроженец Беларуси Александр Виктор Богаткевич, который благодаря своему Трактату о всеобщей библиографии (Rzecz o Bibliografii powszechnej) $)^{43}$ известен как один из первых польских ${ }^{44}$, литовских ${ }^{45}$ и белорусских ${ }^{46}$ библиографоведов и книговедов. Библиография согласно его теории - наука о книге: отрасль теоретического, исторического и практического описания книг, книжных собраний, редкостей, памятников письменности. Эпиграфом к Трактату А. Богаткевичем было избрано многозначное выражение на греческом (!) языке - Гра́ $\mu \alpha \tau \alpha$

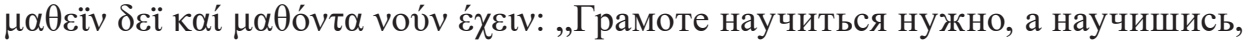
ум иметь" [перевод наш. - Л. Д.]. Отечественным книговедческим опытом А. Богаткевич считал польский, одновременно большое внимание отводил непосредственно работам по библиографическому описанию и изучению книжного наследия в разных странах Европы; рассматривая российские труды, он отмечал их как общие источники по истории славянской письменности и печатного дела, особо выделял роль Виленского университета и „krajowców” в сохранении регионального книжного наследия. Интересно его замечание (в продолжение эпиграфа?), что „ни одно учёное перо с достойной точностью рассеивает по земле Литовской и Польской библиографические сведения, не одна знающая рука, переводя, отыскивая и взвешивая труды, прославленных в науке мужей, сплетает пышный венок для воспитанников славянских Муз; или также, искалеченные болезнью времени, останки следов письменных трудов прадедов, из утраченных добывает, распознает, сравнивает, объясняет"47 (перевод наш. - Л. Д.).

42 J. Lelewel, Bibliograficznych Ksiag Dwoje, w których rozebrane i pomnozone zostaty dwa dzieła Jerzego Samuela Bandtke, Wilno 1823-1826, т. 1-2 (Nakł. J. Zawadzkiego).

43 A. Bohatkiewicz, Rzecz o Bibliografii powszechnej na otworzenie tego kursu w Cesarskim Uniwersytecie Wileńskim dnia 10. stycznia 1829. roku, Wilno 1830.

44 M. Kłossowska, Aleksander Wiktor Bohatkiewicz, ,Studia o Książce” 1971, т. 2, c. 221-239.

45 Теоретик науки о книге Александр Виктор Богаткевич и его Труд о всеобщей библиографии, [в:] A. W. Bohatkiewiczius, Veikalas apie visuotinę bibliografia, parengè A. Braziũnienė, A. Navickienè, S. Rankelienè, Vilnius 2004, c. 253.

46 Л. І. Доўнар, Гісторыя беларускай кнігі, Мінск 2012.

47 Rzecz o Bibliografii powszechnej..., c. 64.

ROCZNIKI BIBLIOTECZNE

ROK LXIII, 2019

(C) for this edition by CNS 
В первой половине XIX в. были предприняты и первые попытки создания национального репертуара книг и периодических изданий Беларуси от начала книгопечатания и до 1847 г. Михалом Пелка-Полиньским ${ }^{48}$, а также - научного труда История славянских типографий в Литве белорусским скориноведом профессором Михаилом Бобровским ${ }^{49}$. Первый труд остался в рукописном виде ${ }^{50}$, второй - утерян.

И только в конце XIX-начале XX в. появляются работы, которые указывают - без всяких сомнений — на принадлежность их содержания к Беларуси, хотя они также ещё представляли собой этапные исследования на пути к созданию собственно белорусской науки о книге. Первая работа Белорусская литература и библиография Александра Ельского, являлась обзором публикаций с 1517 по 1892 г., напечатанным как энциклопедическая статья $^{51}$. Из переписки же А. Ельского с польским лингвистом и этнографом Яном Карловичем известно также, что он „планировал издать „Белорусскую библиографию" отдельной книгой, однако эта задумка осталась неосуществлённой"52. Второй труд — Белорусы Ефима Карского (т. 1-3, 1903-1922 гг.), стал источником информации об изданиях на белорусском языке, вышедших на территории Беларуси, а также по белорусоведению. Собрав и изучив огромный масив информации, Е. Карский сделал и ряд предложений по выявлению, систематизации и разработке принципов идентификации памятников белорусской письменности и печати, подав пример культуры научной книги, организации её содержательного и справочно-библиографического контента ${ }^{53}$. Одновременно оба автора опирались в своих работах на библиографию и словесность (литературу и язык), что показывало на приверженность учёных теоретическим положениям (в том числе А. В. Богаткевича) о тесной связи библиографии с историей словесности.

Белорусское книговедение на этапе своего формирования как науки представляется нам в виде собирательного образа, состоящего из научных

48 В. Е. Леончиков, Общая ретроспективная библиография книг союзных республик, „Вопросы библиотековедения и библиографоведения” 1972, вып. 1, с. 3-5.

49 Ю. Лабынцев, Л. Щавинская, Библиологические исследования профессора Михаила Бобровского и наследие Франциска Скоринь, [в:] Франциск Скорина - личность, деятельность, наследие, современные образы: материалы Международного научного семинара (Полочк, 24 мая 2017 г.), сост. Л. А. Авгуль, Д. Н. Бакун, Минск-Москва 2017, с. 67-71.

50 Хранится в Библиотеке им. Врублевских АН Литвы.

51 Białoruska literatura i bibliografia, [в:] Wielka encyklopedia powszechna ilustrowana, red. J. Aleksandrowicz, Warszawa 1892, т. 8, c. 646-658.

52 В. Е. Лявончыкаў, Бібліятэчна-бібліяграфічная дзейнасиь Аляксандра Ельскага, „Бібліятэчны свет” 2001, № 2, с. 25.

53 В. Е. Лявончыкаў, Кніжная культура ў навуковых працах акадэміка Я. Ф. Карскага, [в:] Духоўныя асновы сучаснай культуры: праблемы захавання культурнай спадчыныь. ХVI Міжнародныя Кірыла-Мяфодзіеўскія чыттанні, прысвечаныя Дням славянскага пісьменства і культуры (Мінск, 26-28 мая 2010 г.): у 2 т., т. 1, Мінск 2011, с. 144.

ROCZNIKI BIBLIOTECZNE

ROK LXIII, 2019

(C) for this edition by CNS 
областей широко понимаемой библиографии, истории и филологии, а также и исследователей, результаты персонифицированного знания которых принадлежат сегодня разным народам (полякам, русским, литовцам, а также и белорусам).

В начале XX в. и особенно с утверждением в 1918 и 1919 гг. первых форм белорусской (национальной) государственности в направлении развития белорусского книговедения работали краеведы, историки, филологи, искусствоведы, библиографы. История белорусской рукописной и печатной книги, библиотечных и архивных собраний, искусство старопечатной книги, определение типологических признаков „белорусской книги” исследовались Ромуальдом Земкевичем, Вацлавом Ластовским, Владимиром Пичетой, Николаем Улащиком, Александром Шлюбским, Николаем Щекотихиным и другими. В 1920-е гг. были созданы такие государственные учреждения, как Белгосбиблиотека (1922), начавшая подготовку и издание Летаnicy бeларускага друку; будущая Академия наук Беларуси - Инбелкульт (19221929), общественная организация Усебеларускае таварыства бібліяфілаў (1927-1929); они взялись за освещение книговедческих вопросов, которые были совсем немного или вообще не исследованы, — это научное изучение культуры книги, книжного дела, искусства книги ${ }^{54}$. В начале 1930 -х гг. были попытки издания отдельного журнала „Кніга — масам” (вышло 7 номеров за 1932 г.), а также Крытыка-бібліяграфічнага зборніка (Госбиблиотека и библиографический институт БССР им. В. И. Ленина, 1934), содержание которых было переполнено вопросами советской идеологии и пропаганды. Основной площадкой для публикации историко-книговедческих материалов служили журналы краеведческого („Наш край”), общественно-литературного („Полымя”, „Узвышша”), культурно-просветительского направления („Асьвета”), в некоторых журналах выделялись специальные рубрики, как например: Кнігапіс, Бібліяграфія, Летапіс беларускага друку, Кнігу і мастаuтва $\check{y} \mathrm{Macbl}^{55}$. Статьи научного характера издавались в „Запісках аддзелу гуманітарных навук" Инбелкульта, в перспективные планы которого входила задача издания полной истории белорусской книги. За границами БССР проблемы истории книги и книгоиздания освещались на страницах таких изданий, как „Крывіч” (Каунас), „Беларуская культура” и „Беларуская Крыніца" (Вильнюс). Круг авторов составляли Владимир Пичета, Владимир Дубовка, Дмитрий Довгялло, Дмитрий Жилунович, Александр Шлюбский,

54 Дополнительно см.: Л. Довнар, Белорусское книговедение и национальное возрождение 1920-х годов, „Knygotyra” 2007, т. 48, с. 53-66, https://www.journals.vu.lt/knygotyra/article/ view/8111/5982.

55 Например: Г. Перлін, Да гісторыі яурэйскага друку на Беларусі, „Наш край” 1927, № 8-9, с. 11-15; Хв. Шынклер, [рец.] Чатырохсотлец̧ьиее беларускага друку (1525-1926). Зборнік. Выл. Інстылуту Беларускае Культурыл. Менск, 1926, „Узвышша” 1928, № 1, с. $182-185$.

ROCZNIKI BIBLIOTECZNE

ROK LXIII, 2019

(C) for this edition by CNS 
Николай Касперович, Михаил Мелешко, Степан Некрашевич, Иосиф Симановский, Юлия Бибила, Нина Ватаци, Игнат Дворчанин, Адам Станкевич.

За пределами БССР в 1920-е гг. выделяется библиотечно-библиографическая деятельность Александра Ружанцова (Aleksandras Ružancovas, псевд. Александр Смаленец; 1893-1966), который сотрудничал в этой области с белорусскими виленскими издателями, в первую очередь с Максимом Горецким („Беларускія ведамасці”, Вильня, 1921-1922), был автором статей ковенского издания В. Ластовского и К. Дуж-Душевского „Крывіч” (1923-1927), поддерживал контакты с латгальскими белорусами (Константином Езовитовым ${ }^{56}$ ), которые в свою очередь также занимались историей белорусской книги. В 1924 г. в журнале „Knygos”57 была опубликована первая работа А. Ружанцова „книговедческой тематики” - библиография белорусских книг, изданных в независимой Литве в 1919-1921 гг. ${ }^{58}$ Работая библиотекарем военной библиотеки, он также преподавал курс прикладной библиографии на библиографических курсах при Ковенском университете, а после издания своего первого специализированного библиографического справочника на литовском языке Lietuvos Karo bibliografija (Литовская военная библиография) $)^{59}$ снискал имя „отца литовской библиографии” ${ }^{60}$. Подготовленные А. Ружанцовым за годы его жизни и деятельности библиографические справочники и сегодня не потеряли своей актуальности ${ }^{61}$, хотя и не получили отражения в истории библиографоведческой мысли Беларуси 62 .

Феноменальным же событием для белорусской эмиграции, а со временем и для всей книжной культуры Беларуси, стал капитальный труд Вацлава Ластовского - Гісторыя беларускай (крыуцскай) кнігі: Спроба паясьніцุельнай кнігопісі ад канц̧а Х да пачатку ХІХ стагодзьдзя (1926), подобного которому на то время ещё не имели ни русские, ни украинцы, ни литов-

56 В. Герасімаў, Да праўды светлай, братка, йдзі!, „Полымя” 1994, № 8, с. 170-189.

57 A. Smaleniec, Gudų knygos ir laikraščiai Lietuvos nepriklausomoj dalyje 1919-1921, „Knygos” 1924, № 1, c. 94-95.

58 А. Антонаў, Аляксандр Ружанциоў: Накіды да біяграфіi, http://www.belhistory.eu/ andrej-antona\%D1\%9E-alyaksandr-ruzhanco\%D1\%9E-nakidy-da-biyagrafii/ [дата доступа: 21.02.2020].

59 A. Ružancovas, Lietuvos karo bibliografija, 1917-1922, Kaunas 1923.

60 А. Ружанцов с 1928 по 1943 г. редактировал журнал „Bibliografijos žinios” („Библиографические известия"), издаваемый Вацлавом Биржишкой, о чём в 1980 г. писал Левас Владимировас (1912-1999) в статье Путями и лжепутями жизни и библиографии - см.: L. Vladimirovas, Gyvenimo ir bibliografijos keliais ir klystkeliais, „Knygotyra” 1980, т. 8, с. 32. См. также: B. Kviklys, Bibliografui A. Ružaniec-Ružancovui 70 metu, „Knygų Lentyna” 1963 , № 2, с. 35-36.

61 А. Антонаў, Аляксандр Ружанциоу: Накіды да біяграфіi...

62 См. раздел: Развіцицё бібліяграфіі беларускага замежжа, [в:] В. І. Саітава, В. Е. Лявончыкаў, Т. В. Кузьмініч, Бібліяграфазнаўства. Гісторыя, рэд. Т. В. Кузьмініч, Мінск 2017, c. $184-196$. 
цы $^{63}$. Специфика представленной концепции истории белорусской книги В. Ластовского заключались в синкретичности и многогранности ее содержательного контента, в понимании и значении книги не только с точки зрения либо библиографической (как объекта учета, описания), либо только книговедческой (истории книги), либо книговедческо-библиографической, а шире - в единстве письма, языка, письменности и искусства, как важнейших составляющих национальной культуры и истории; в единстве создания, распространения и бытования рукописного и печатного наследия Беларуси, т. е. в историко-культурологическом аспекте, что даёт право называть труд В. Ластовского первым, в полном смысле, исследованием по истории книжной культуры Беларуси ${ }^{64}$.

Такая широта подхода, была близка взглядам украинских учёных-библиографов Николая Сагарды, Юрия Ковалевского, Степана Постернака ${ }^{65}$, позиции русского книговеда Николая Лисовского, акцентировавшего внимание на взаимосвязи книговедения с палеографией и историей литературы, а также украинского и польского книговеда Леона Быковского, считавшего более важными связи книговедения с историей культуры, социокультурной средой и национальной идеей ${ }^{66}$.

У В. Ластовского впервые очерчивается и образ понятия белорусской книги, её сущностные типологические признаки, книги - в широком значении (в том числе и первые свидетельства белорусской письменности на разных носителях: камне, металле, глине, пергамене, бумаге; на разных предметах: медальонах, крестах, печатях, посуде), — являющейся тем документом, который свидетельствует не только о существовании белорусской нации, её давней истории, но и о её особенностях, отличии от других народов (русских, поляков) и главнейшим идентификационным признаком выступает язык, кроме этого - территория и авторство, рассматриваемые в историческом, религиозном и политическом контекстах, во взаимовлияющем культурном пространстве разных народов и одновременно формирующие пространство национальной мысли. Гісторыя беларускай (крыўскай)

63 А. Суша, Першая гісторыя беларускай кнігі і яе стварэнне, [в:] В. Ластоўскі, Гісторыя беларускай (крыусскай) кнісі, Мінск 2012, с. 3-30.

64 Дополнительно см.: Л. І. Доўнар, „У горадзе маім - такім мацоўным - адзін я быў!”, [в:] Беларуская кніга ў кантэксие сусветнай кніжнай культуры, Мінск 2011, вып. 3, c. 139-168; eadem, До и после Ваилава Ластовского: белорусская наука о книге в контексте персонального книговедения, „Knygotyra” 2013, т. 60, с. 169-190, https://www.journals.vu.lt/ knygotyra/article/view/1367/769 [дата доступа: 20.02.2020]; L. Dounar, Wacław Eastouski i kultura książki Białorusi, пер. K. Migoń, „Roczniki Biblioteczne” 2013, № 56, c. 29-53.

65 В. Е. Лявончыкаў, Общая ретроспективная библиография книг союзных республик „Вопросы библиотековедения и библиографоведения” 1972, вып. 1, с. 3-15.

66 Н. К. Леликова, Становление и развитие книговедческой и библиографической наук в России в XIX-первой трети ХХ века, Санкт-Петербург 2004, с. 259. 
кнігі В. Ластовского стала первым опытом целостного подхода к истории белорусской книги ${ }^{67}$ в единстве её материального, духовного и художественного начал.

Среди последних книговедческих работ В. Ластовского, относящихся к периоду его высылки в Саратов, - программа лекций по Истории книги 68 . Сохранилась только рукопись программы, датируемая 24.09.1936 ${ }^{69}$. Это тематический список 10 лекций, каждая из которых имеет свой определённый круг вопросов или тематических направлений. Интересно, что В. Ластовский начинает свои лекции с рассмотрения воззрений „на письмо как на божественное откровение”, а заканчивает размышлениями о том, что „книга - не материальный предмет, а орудие политической борьбы”, представляет „периодизацию книг по социологическому принципу”, завершая цикл лекций вопросом о ,задании и роли библиотекаря в эпоху диктатуры пролетариата"70. Тезисные положения Программы, хотя и скупо, но всё же отражают концептуальный подход В. Ластовского к изучению книги, которую, по его мнению, необходимо анализировать как историческое явление на фоне общечеловеческого развития; подтверждают понимание и глубокую убеждённость Ластовского-книговеда ценностного значения книги для каждого народа, а значит и для всего человечества. В. Ластовский надеялся, что его книга „паміма многіх яе недастаткаў, прынясе карысьць нашай адраджаючай пісьменнасьці, хоць бы пабуджаючы другіх да працавітых досьледаў на полі нашай мінуўшчыны, асабліва пісьменнасьці [...]"71.

В целом 1920-е годы в исследовании истории белорусской письменности, рукописных и старопечатных изданий были необычайно плодовитыми, открывали большие перспективы для новых исследований в области книговедения, изучения всего культурного наследия Беларуси, чему, безусловно, способствовала белоруссизация. Однако после книговедческого всплеска 1920-х гг. прошло ещё не одно десятилетие, прежде чем появились продолжатели и последователи дела В. Ластовского, а его главный труд Гісторыя беларускай (крыускай) кнігі был переиздан.

Первые положительные сдвиги на этапе развития белорусского советского книговедения наметились со второй половины 1950-х гг., когда иссле-

${ }^{67}$ См.: А. Шлюбскі, Рэиэнзія, „Маладняк” 1926, № 5, с. 104-105; А. Шлюбскі, Рэиэнзія, „Полымя” 1926, № 5, с. 144-147.

68 Программа лекций В. Ластовского по „Истории книги”, Саратов 1936, с. 2 - См.: А. В. Зюзин, Из материалов В. У. Ластовского, [в:] Беларуская кніга ў кантэксие сусветнай кніжнай культуры, Мінск 2011, вып. 3, с. 171.

69 Из бумаг В. У. Ластовского, подготовка и публикация текста Н. А. Попковой, [в:] Беларуская кніга у кантэксие сусветнай кніжнай культуры, Мінск 2011, вып. 3, с. 196-198.

70 Ibidem.

71 В. Ластоўскі, Гісторыя беларускай (крыусскай) кнігі: Спроба паясніцельнай кнігапісі ад канцуа Х да пачатку ХІХ стагоддзя, Коўна 1926, с. VIII. 
дование отдельных вопросов по истории книги постепенно стало возвращаться в общую проблематику гуманитарных наук - филологии, истории, философии, искусства, культуры, а книговедение как наука получило новое возрождение.

Вновь была актуализирована и стала ведущей скориноведческая тема ${ }^{72}$, а в связи с этим встал вопрос теоретического определения понятия „белорусская книга"73, продолжилась научно-библиографическая работа по изучению кирилловской печати ${ }^{74}$, появился первый специальный научный сборник Из истории книги, библиотечного дела и библиографии в Белоруссии (1970) ${ }^{75}$, литературоведами осуществлены первые публикации первоисточников по истории книги ${ }^{76}$ и первые в Беларуси энциклопедические статьи, посвящённые книговедению ${ }^{77}$. Среди известных ученых филологов, историков, философов и искусствоведов, подвижников белорусского книговедения - Степан Александрович, Марат Ботвинник, Георгий Голенченко, Анатолий Грицкевич, Виктор Дорошкевич, Аркадий Журавский, Геннадий Киселёв, Александр Коршунов, Адам Мальдис, Владимир Мархель, Вячеслав Чемерицкий, Виктор Шматов и многие другие. Также и в среде библиотечной интеллигенции исследованиями истории книги и книжных собраний продолжали заниматься

72 Например: 450 год беларускага кнігадрукавання, Мінск 1968; Белорусский просветитель Франииск Скорина и начало книгопечатания в Белоруссии и Литве, ред. А. Сидоров, Москва 1979.

73 См. также следующие предложения по идентификации белорусской книги: 1965 г. Г. Я. Голенченко, История белорусского книгопечатания XVI-XVIII (кириллического), Автореферат диссертации на соискание ученой степени кандидата исторических наук, Москва 1965, с. 15-16: 1) территориальное месторасположение типографий, 2) содержание книги, предназначенность белорусскому читателю, ориентация книгоиздательства на белорусский рынок, 3) происхождение авторов рукописи, работников типографии, книгоиздания, национальный состав работников типографии, 4) черты национальной культуры в оформлении, орнаментах, графике изданий; 1967 г. - А. И. Журавский, А. Н. Булыко, 450 лет белорусского книгопечатания, [в:] Книга. Исследования и материалы, Москва 1967, сб. 14, с. 105: издания, осуществлявшиеся белорусами и предназначались для распространения среди белорусского населения независимо от места создания и языка; 1977 г. - Е. С. Умецкая, История книгоиздания в Белоруссии в первой трети ХІХ века (1801-1832 г2.), Автореферат диссертации на соискание ученой степени кандидата исторических наук, Минск 1977: комплекс признаков: автор текста или переводчик, редакционное, техническое и художественное ее выполнение.

${ }^{74}$ Г. Я. Голенченко, Библиографический список белорусских старопечатных изданий XVI-XVIII вв., Минск 1961; А. А. Сокольчик, Дооктябрьская книга на русском языке о Белоруссии (1768-1917), Минск 1976.

75 Издавался Центральной научной библиотеки им. Я. Коласа НАН Беларуси.

76 Хрэстаматыя па старажытнай беларускай літаратуры, уклад. А. Ф. Коршунаў, Мінск 1959; Пачынальнікі. 3 гісторыка-літаратурных матэрыялаў ХІХ ст., уклад. Г. В. Кісялёў, Мінск 1977.

77 С. Х. Александровіч, Кнігазнаўства, [в:] Беларуская Савецкая Эниыклапедыя: у 12 m., Мінск 1972, т. 6, с. 39.

ROCZNIKI BIBLIOTECZNE

ROK LXIII, 2019

(C) for this edition by CNS 
Нина Ватаци, Лидия Збралевич, Людмила Новицкая, Семён Ошерович, Адам Сокольчик, Евгения Умецкая, Валентина Цыбуля и другие.

В 1970-е годы активизируются научные книговедческие исследования на библиотечном факультете Минского института культуры (создан в 1975 г.), защищаются первые кандидатские диссертации по книговедческим проблемам: в 1973 г. защищена диссертация Раисы Ровиной Развитие технической литературы в Белорусской ССР (1919-1970 г2.); в 1974 г. - Изы Мельник Журнал „В мире книг” как тип книговедческого издания (19581972 г2.); 1977 г. - Евгении Умецкой История книгоиздания в Беларуси в первой трти ХІХ века (1801- 1832 г2.).

Белорусская историко-книговедческая проблематика находит отражение и в первых советских специальных энциклопедических изданиях - как Книговедение (1982), главным редактором которого являлся профессор Николай Сикорский $^{78}$, белорус по происхождению, возглавивший кафедру книговедения и редактирования Московского полиграфического института (1954-1972), являвшийся главным редактором научного сборника Книга. Исследования и материаль (1959-1992) и директором ГБЛ СССР им. В. И. Ленина (19721979). Н. Сикорский внес значительный вклад в развитие советского книговедения, нового осознания и возрождения статуса книговедения как науки ${ }^{79}$.

В основе большинства книговедческих исследований Беларуси периода 1980-х гг. выступают статистический, библиографический и содержательный методы анализа изданий (Р. Ровина, Анастасия Соломко, София Павлова, Татьяна Кузьминич, Эльвира Судья, Ирина Дриго), применяются также социологические методы при изучении особенностей читательского адреса (детей - Валентина Бигеза, рабочих — Зинаида Клецкая) ${ }^{80}$, выделяются работы источниковедческого и историографического направления (Е. Умецкая, Лидия Збралевич). В числе весомых результатов на стыке библиографии с историей гуманистики и книговедения стали такие капитальные труды,

78 Н. М. Сикорский (1921-1997) родился в с. Хутор Червенского района БССР, книговед, доктор филологических наук, окончил Московский полиграфический институт (1948), остался работать а Москве. С начала 1970-х гг. добивался реализации идеи издания энциклопедического издания, посвященного книговедению. Был одним из инициаторов проведения Всесоюзных научных конференций по проблемах книговедения (с 1971); возобновления „Фёдоровских чтений” (1973); создания Всесоюзного добровольного общества любителей книги (1974). В честь Н. М. Сикорского с 2008 г. в Москве Научным центром исследований истории книжной культуры РАН проводятся „Чтения им. Н. М. Сикорского”. См. также: Е. Л. Немировский, Сикорский Николай Михайлович, [в:] Книга: энциклопедия, Москва 1999, с. 588.

79 Л. І. Доўнар, Беларуская навука пра кнігу у кантэксие персанальнага кнігазнаўства, „Веснік Беларускага дзяржаўнага ўніверсітэта культуры і мастацтваў” 2014, № 1, с. 114.

80 В. А. Касап, Кнігазнаўчыя даследаванні у Беларускім дзяржаўным універсітэие культуры і мастаитвай, [в:] Беларуская кніга у кантэксие сусветнай кніжнай культуры, Мінск 2008, вып. 2, с. 121.

ROCZNIKI BIBLIOTECZNE

ROK LXIII, 2019

(C) for this edition by CNS 
как Кніга Беларусі, 1517-1917: зводны каталог (Минск, 1986), а также энциклопедический справочник Франщыск Скарына і яго час (Минск, 1988) ${ }^{81}$, появившиеся благодаря значительным усилиям историка-книговеда Георгия Голенченки и ряда его сподвижников.

Хотя идеологическая атмосфера советской цензуры и отразилась на недостаточной полноте историографической, источниковедческой и методологической базы данных работ, но шаг за шагом белорусское книговедение расширяло свою предметную научно-исследвательскую и образовательно-просветительскую область, пополнялось новыми кадрами ${ }^{82}$. Определённым явлением для Беларуси в открытии широкого круга исследовательских тем книговедческого направления стало обращение к созданию библиографических пособий, посвящённых крупнейшим мировым книговедам (инициировано Юрием Лабынцевым и Татьяной Рощиной) ${ }^{83}$, а также включение в исследовательское пространство научной категории „книжная культура” (НББ, ЦНБ НАНБ) ${ }^{84}$. Тем не менее, вплоть до середины 1990-х гг. книговедческая тематика в Беларуси не являлась отдельным и самостоятельным поводом для организации и проведения каких-либо научных конференций ${ }^{85}$, а только вкраплялась в общую гуманитарную конву, в том числе, Скориновских чтений (с 1986 г.).

Сегодня же среди основных систематических книговедческих научных мероприятий можно назвать Книговедческие чтения (проводятся НББ с 1998 г.), Кирилло-Мефодиевские чтения (проводятся БГУКИ с 1997 г.) и Берковские чтения (проводятся ЦНБ НАНБ с 2011 г.). Основной площадкой представления результатов научных изысканий стали специальные научные из-

81 Издания не содержали никаких даже упоминаний о В. Ластовском. Дополнения внесены в издание на русском языке, которое вышло в 1990 г. См.: Франщиск Скорина и его время: энииклопедический справочник, ред. И. П. Шамякин et al., Минск 1990.

82 См.: А. А. Волк, А. И. Ракович, Книгоиздательское дело в Белоруссии: исторический очерк, Минск 1977; А. І. Раковіч, Кнігазнаўства, [в:] Беларуская ССР: кароткая энцыклапедыя, Мінск 1980, т. 3, с. 273.

83 Профессор Кшиштоф Мигонь: библиографический указатель, сост. Ю. А. Лабынцев, Т. И. Рощина, Минск 1990 (Крупнейшие книговеды мира: серия библиографических указателей).

84 Например: Кніжная культура Беларусі: да 500-годдзя з дня нараджэння Ф. Скарыны, Мінск 1991; Ю. А. Лабынцев, Международная славяноведческая программа „История книжной культуры Подляшья”: (текст докл. на Междунар. иерковно-науч. конф., посвящ. 1000-летию Правосл. иеркви на Беларуси, 25 сент. 1992 г.), Мінск 1992. Также см.: Л. И. Довнар, Т. А. Самойлюк, Книжная культура Беларуси: концептуальные основы и пути реализаиии научного проекта Белорусского государственного университета культуры и искусств, [в:] Книга - источник культуры: проблемы и методы исследования: материалы Междунар. науч. конф. (Минск, 25-27 ноября 2008 г.), Москва 2008, с. 123-131.

85 Началом послужила международная конференция, организованная в 1996 г.: Недзяржаўная выдавеикая дзейнасиь у Беларусі: гісторыя і сучаснасиь: матэрыялы Міжнар. навук.-практ. канф. (Мінск, 3-4 кастр. 1996 г.), Мінск 1997.

ROCZNIKI BIBLIOTECZNE

ROK LXIII, 2019

(C) for this edition by CNS 
дания: Здабыткі: дакументальныя помнікі на Беларусі (издаются с 1995 г.) ${ }^{86}$, Матэрыялы Міжнародных кнігазнаўчых чытанняў (с 2000 г.), Бібліятэчны веснік (с 2009 г.) - НББ, Берковские чтения (с 2011 г.) - ЦНБ НАНБ, Веснік Беларускага дзяржаўнага ўніверсітэта культуры і мастацтваў (с 2002 г.), Беларуская кніга у кантэксие сусветнай кніжнай культуры (с 2006 г.) $)^{87}$ - БГУКИ, Труды Белорусского государственного технологического университета $(\text { c 1993 })^{88}$ - БГТУ, в содержании которых отражаются основные направления развития в Беларуси за последнее 20-тилетие как исторического, так и теоретического книговедении, что в свою очередь свидетельствует, осмелимся сказать, о новом этапе белорусского книговедения - этапе зрелости.

Первые попытки историографического анализа именно белорусской науки о книге - насколько было возможно в энциклопедической статье впервые были предприняты Л. Збралевич (в 1986 г.) ${ }^{89}$, а немногим позже более развёрнуто - и Валерием Герасимовым, также в энциклопедической статье Кнігазнаўства (в 1997 г.) $)^{90}$, в которой были рассмотрены вопросы становления и развития белорусской науки о книге в связи с определёнными этапами истории белорусской письменности и печати; были введены новые имена исследователей, отмечены научные центры книговедения. С 1996 г. в БГУКИ начал работу Совета по защите дисертаций по специальности „библиотековедение, библиографоведение и книговедение"91, а также, прежде всего, благодаря деятельности отделов редких книг НББ, ЦНБ НАНБ, БГУКИ статус науки о книге был подтверждён. В 2006 г. было объявлено о создании в Беларуси координирующего книговедческого центра - Научно-исследовательского отдела книговедения в НББ (возглавляла Т. Рощина).

Активное и заинтересованное обсуждение проблем и перспектив развития белорусской науки о книге было предложено на международной научной

86 Т. А. Сапега, Белорусский книговедческий сборник „Здабыткі” (1995-2013), [в:] Книга в информационном обществе: материаль Тринадияатой Международной научной конференции по проблемам книговедения (Москва, 28-30 апреля 2014 г.): в 4 ч., ч. 1, Москва 2014, c. 90-91.

87 Л. І. Доўнар, [в:] Беларуская кніга ў кантэксие сусветнай кніжнай культуры ў асобах i працах, [в:] Матэрыяль ХІІ Міжнародных кнігазнаўчых чытанняў „Кніжная культура Беларусі: погляд праз стагоддзі” (7-8 красавіка 2016 г.), склад. Т. А. Сапега, А. А. Суша, Мінск 2016, с. 336-340.

88 И. В. Войтов, В. И. Куликович, Научныйжсурнал по издательскому делу и полиграфии как отражение перспектив развития отрасли, [в:] Матэрыяль міжнароднага кангрэса „500 гадоў беларускага кнігадрукавання”. ХІІІ Міжнародныя кнігазнауччыя чытанні (Мінск, 14-15 верасня 2017 г.): у 2 ч., ч. 2, Мінск 2017, с. 254-258.

89 Л. І. Збралевіч, Кнігазнаўства, [в:] Энизыклапедыя літаратуры і мастащтва Беларусі: y 5 m., т. 3, Мінск 1986 , с. 83-84.

90 В. М. Герасімаў, Кнігазнаўства, [в:] Эниылклапедыя гісторыі Беларусі: у 6 m., т. 4, гал. рэд. Г. П. Пашкоў, Мінск 1997, с. 213-214; idem, Беларуская энизыклапедыя: у 18 m., т. 8, гал. рэд. Г. П. Пашкоў, Мінск 1999, с. 361-362.

91 Л. І. Доўнар, Праблемнае поле беларускай кнігазнауччай навукі і адукащылі, [в:] Беларуская кніга ў кантэксие сусветнай кніжнай культуры у 2 ч., ч. 2, Мінск 2006, вып. 1, с. 208.

ROCZNIKI BIBLIOTECZNE

ROK LXIII, 2019

(C) for this edition by CNS 
конференции „Беларуская кніга ў кантэксце сусветнай кніжнай культуры” (2006 г., БГУКИ), где с соответствующими концептуальными докладами выступили Николай Николаев, Тамара Самойлюк, Лариса Довнар ${ }^{92}$. Принципиально важное значение имело представление на данной конференции теоретических вопросов, особенно, определения понятия „беларуская кніга", высказанное профессором БГУКИ В. Е. Леончиковым, который, принимая во внимание гетерогенный характер термина, предложил учитывать в комплексе такие сущностные признаки, как язык, авторство, территория, содержание книги; раскрыл также объём данного понятия ${ }^{93}$, подчеркнул его различие с понятием „нацыянальная кніга” (для первого используется этнонимичная, а для второго - политонимичная характеристики, что свидетельствует об отнесении книги к определенному народу (нации), а в другом случае - к определенной стране), высказался и о понятии „нацыянальны дакумент" в тематическом сборнике НББ 94 .

В 2008 г. был осуществелён и специальный выпуск сборника научных трудов Беларуская кніга ў кантэксие сусветнай кніжнай культуры 95 , посвященный анализу опыта книговедческих исследований в НББ, Президентской библиотеке Республики Беларусь, Национальном музее истории и культуры Беларуси, БГУКИ, ЦНБ НАНБ, Национальной книжной палате Беларуси ${ }^{96}$, в составе коллективов которых трудились уже несколько поколений книговедов: Л. Збралевич, Е. Умецкая, Р. Чигирёва, Т. Рощина, В. Герасимов, Ю. Лаврик, Н. Берёзкина, А. Стефанович, Е. Титовец, Г. Киреева, Т. Самойлюк, Т. Сапега, Е. Иванова и другие.

92 См.: Беларуская кніга ў кантэксие сусветнай кніжнай культуры у 2 ч., Мінск 2006, вып. 1.

93 В. Е. Лявончыкаў, Беларуская кніга: падыходы да вызначэння зместу і аб'ёму паняция, [в:] Беларуская кніга у кантэксие сусветнай кніжнай культуры у 2 ч., ч. 1, Мінск 2006, вып. 1, с. 17: „,а) беларускамоўныя кнігі, выдадзеныя як на тэрыторыі Беларусі, так і за яе межамі; б) кнігі на іншых мовах (лацінскай, рускай, польскай і іншых), напісаныя аўтарамі беларускага паходжання (ліцвінамі, заходнерусінамі, беларусамі) і грамадзянамі Беларусі, незалежна ад месца выдання гэтых кніг; в) пераклады кніг на беларускую мову замежных аўтараў (на іншых мовах), а таксама пераклады беларускіх аўтараў на замежныя мовы; г) кнігі, выдадзеныя выдавецтвамі і тыпаграфіямі на тэрыторыі Беларускай дзяржавы ці на беларускай этнічнай тэрыторыі, калі Беларусь не мела дзяржаўнасці".

94 В. Е. Лявончыкаў, Нацыянальны дакумент: падыходы да вызначэння зместу и аб'ёму паняиия, [в:] Нацыянальны дакумент як аб’ект дзейнасиі бібліятэк Беларусі, склад. Т. В. Кузьмініч, Мінск 2010, с. 11-21.

95 Беларуская кніга ў кантэксие сусветнай кніжнай культуры, Мінск 2008, вып. 2.

96 См. сайт о деятельности Национальной книжной палаты Беларуси: https://natbook. org.by/ [дата доступа: 21.08.2018], а также издания, в которых представлены ежегодные статистические данные о печати Беларуси - Друк Беларусі или Печать Беларуси в иифрах, сводные и аналитические материалы по десятилетиям - например, Друк Беларусі, 2001-2010: статыстычны зборнік, Мінск 2012, в сравнении с другими странами - например, Печать стран СНГ в иифррах, 2015, Минск 2016. 
Современная белорусская наука о книге характеризуется количественным и качественным ростом научных работ, парадигмальной основой которых выступает книжная культура, о чем свидетельствуют работы Н. Николаева, посвященные книжной культуре Великого Княжества Литовского 97 , Т. Самойлюк - современным тенденциям исследования книжной культуры $^{98}$, феномену религиозной книжности в культуре ${ }^{99}$, Т. Сапега - феномену печатной книги ${ }^{100}$ и книжной культуре ${ }^{101}$, Т. Корниловой - аксиосфере книги ${ }^{102}$, Л. Довнар - философско-культурологическим подходам в изучении белорусской книги ${ }^{103}$, белорусской книге как универсуму культуры ${ }^{104}$, когнитивной стратегии книжной культуры ${ }^{105}$, „книге” и „документу”106, которые могут составить определенную методологическую основу современных исследований книги.

97 М. В. Нікалаеў, Кніжная культура Вялікага Княства Літоусскага, [в:] Гісторыя беларускай кнігі: у 2 т., т. 1, Мінск 2009; idem, Книжная культура Великого Княжества Литовского, Автореферат диссертации на соискание ученой степени доктора филологических наук, Санкт-Петербург 1997.

98 Т. А. Самойлюк, Кніжная культура: сучасныя тэндэнцьі навуковых даследаванняў, [в:] Беларуская кніга ў кантэксие сусветнай кніжнай культуры, Мінск 2008, вып. 2, с. 39-47.

99 Т. А. Самойлюк, Религиозная книга как книговедческая категория: фукичи и свойства, [в:] Беларуская кніга у кантэксие сусветнай кніжнай культуры, Мінск 2017, вып. 7, c. 121-133; eadem, Религиозная книга как книговедческая категория, [в:] Наука о книге. Традиции и инновации: материаль Двенадияатой Международной научной конференции по проблемам книговедения (Москва, 28-30 апреля 2009 г.): К 50-летию сборника „Книга. Исследования и материаль”": в 4 ч., ч. 1, Москва 2009, с. 277-281.

100 Т. А. Сапега, Друкаваная кніга як феномен культуры, [в:] Беларуская кніга ўкантэксие сусветнай кніжнай культуры у 2 ч., ч. 2, Мінск 2006, вып. 1, с. 56-68.

101 Т. А. Сапего, Книжная культура Радзивиллов: теоретическое обоснование проблемы, [в:] Наука о книге..., ч. 4, Москва 2009, с. 510-512.

102 Т. У. Карнілава, Аксіясфера „Малой падарожнай кніжкі”, [в:] Матэрыялы Х Міжнародных кнігазнаўчых чытанняў „Кніжная культура Беларусі XVI-сярэдзіны XVII ст.: да 440-годдзя выдавецкай дзейнасиі Мамонічай” (Мінск, 17-18 красавіка 2014 г.), Мінск 2014, c. $73-77$.

103 Л. И. Довнар, Книжная культура как философско-культурологическая категория библиологии (к постановке проблемы), [в:] Наука о книге..., ч. 1, Москва 2009, с. 462-465; eadem, Кніга і дакумент у кантэксие кагнітыўна-аксіялагічнага падыходу, „Веснік Беларускага дзяржаўнага ўніверсітэта культуры і мастацтваў” 2015, № 1, с. 132-141.

104 Л. Довнар, Белорусская книга как универсум национальной культуры, „Knygotyra” 2010 , т. 54, с. 161-172, https://www.journals.vu.lt/knygotyra/article/view/3580/2593 [доступ: 21.08.2018].

105 Л. І. Доўнар, Кніжная культура Беларусі паміж кагнітыўнай стратэгіяй ітактыкай інструменталізацыі, [в:] Скориновские чтения 2016: книга как феномен культуры, искусства, технологии: материалы II Международного форума (Минск, 6-7 сентября 2016 г.), Минск 2016, c. 28-32, https://www.belstu.by/conferencesandexhibitions/2016-god/skorinovskie-chteniya2016-kniga-kak-fenomen-kultury-iskusstva-tehnologii.htm1274c [доступ: 21.08.2018].

106 Л. Довнар, Книга и документ: „иена” вопроса, „Кnygotyra” 2011, т. 57, с. 38-48, https://www.journals.vu.lt/knygotyra/article/view/1491/879 [доступ: 21.08.2018]. 
В комплексе публикаций, посвященных вопросам методологии истории белорусской книги и книговедения, особого внимания заслуживают статьи T. Рощиной, написанные о проблемах информационно-библиографического обеспечения истории библиотек ${ }^{107}$, белорусского книговедения ${ }^{108}$; Т. Самойлюк - о религиозной книге как книговедческой категории ${ }^{109}$, В. Герасимова - по изучению книговедческого наследия белорусского зарубежья 110 и истории книги в годы Великой Отечественной войны ${ }^{111}$, Ю. Лаврика - по историческому книговедению ${ }^{112}$, истории книжных коллекций и истории библиотек Беларуси ${ }^{113}$, Л. Ковкель - истории чтения ${ }^{114}$, Л. Довнар - по вопросам персонального ${ }^{115}$ и регионального книговедения ${ }^{116}$, истории бе-

107 Т. И. Рощина, Белорусские исторические книжные коллекции в фондах Начиональной библиотеки Белоруссии (проблемы изучения), [в:] Белорусский сборник: статьи и материаль по истории и культуре Белоруссии, Санкт-Петербург, 2002, вып. 2, с. 199-202.

108 Т. І. Рошчына, Інфармачыйна-бібліяграфічныля патрэбы беларускага кнігазнаўства, [в:] Материаль II Международного конгресса „Библиотека как феномен культуры”, Минск, 22-23 октября 2014 г., сост. А. А. Суша, ред. Р. С. Мотульский, Минск 2014, с. 132-137.

109 Т. А. Самойлюк, Религиозная книга как книговедческая категория, [в:] Наука о книге..., ч. 1, Москва 2009, с. 277-281; еadem, Религиозная книга как книговедческая категория: фукиии и свойства..., с. 121-133.

110 В. М. Герасімаў, Да праблемы гістарыяграфіі кнігазнаўства беларускага замежжа, [в:] Беларуская кніга у кантэксие сусветнай кніжнай культуры у 2 ч., ч. 2, Мінск 2006, вып. 1, с. 108-114.

111 В. М. Герасімаў, Друк Беларусі 1941-1945 г2. у фондах Прэзідэникай бібліятэкі Рэспублікі Беларусь як аб’ект бібліяграфічнай і культурнай ідэнтыфікацыі, [в:] Духоўныя асновы сучаснай культуры..., т. 1, с. 114-126.

112 Ю. Лаўрык, Гістарычнае кнігазнаўства як самастойная навука: да пастаноўкі праблемы, [в:] Беларуская кніга у кантэксие сусветнай кніжнай культуры, Мінск 2014, вып. 5, с. 34-43; idem, Да праблемы вывучэння традыцыйнай габрэйскай кніжнай культуры на беларускіх землях, [в:] Современные проблемы книжной культуры: основные тендениии и перспективы развития: материаль Международного научного семинара (Минск, 2-3 апреля 2014 г.), Минск-Москва 2014, с. 30-34.

113 Ю. Лаўрык, Бібліятэкі на Беларусі у 2-ой пал. XVI-1-ай пал. ХIX ст.: (Нарыс тэндэнщьій развіция), „Наша вера” 2007, № 2, с. 68-71; idem, ,Книг вщеляких русских, польских и латинских..." Прыватныя бібліятэкі прававслаўных іерархаў Рэчы Паспалітай канца XVI-1-й паловы XVII cm., „Роднае слова” 2012, № 3, с. 5-8; idem, Кнігі і кнігазборы Куцеінскага манастыра ў сярэдзіне XVII cm., Мінск 2012; idem, Найдаўнейшыля беларускія кніжніuъb, „Роднае слова” 2006, № 2, с. 78-81; № 4, с. 80-83.

114 Л. Коўкель, Праблемы даследавання гісторыі чытання ў Беларусі у ХІХ ст., [в:] Беларуская кніга у кантэксие сусветнай кніжнай культуры, Мінск 2015, вып. 6, с. 85-92.

115 Л. И. Довнар, О роли личности в развитии науки о книге, или Штудии Кшиштофа Мигоня, [в:] Берковские чтения. Книжная культура в контексте международных контактов: материаль Международной научной конференции (Минск, 25-26 мая 2011 г.), МинскМосква 2011, с. 124-128; еadem, Беларуская навука пра кнігу у кантэксие персанальнага кнігазнаўства, „Веснік Беларускага дзяржаўнага ўніверсітэта культуры і мастацтваў” 2014 , № 1, c. 107-119.

116 Л. І. Доўнар, Рэгіянальныя даследаванні гісторыі кнігі у Беларусі: да пытання аб рэгіянальным кнігазнаўстве, [в:] Материаль VII Международных книговедческих чтений

ROCZNIKI BIBLIOTECZNE

ROK LXIII, 2019

(C) for this edition by CNS 
лорусского книговедения ${ }^{117}$. Представлено белорусское книговедение и теоретико-прикладными исследованиями по типологии отраслевой книги: религиозной ${ }^{118}$, медицинской учебной книги ${ }^{119}$, художественных сериальных изданий ${ }^{120}$. Взаимосвязаны с ними проблемы изучения функциональной сущности и свойств книги (Т. Самойлюк ${ }^{121}$, Н. Вайцехович $^{122}$ Л. Довнар ${ }^{123}$, Л. Петровичева ${ }^{124}$, Е. Богданович ${ }^{125}$ ), а также проблемы теории учебной книги $^{126}$, типологии читателей ${ }^{127}$.

„Библиотеки и политика открытого доступа к информации и знаниям” (Минск, 10-11 ноября 2011 г.), сост. Л. Г. Кирюхина, Минск 2011, с. 62-71.

117 Л. І. Доўнар, Беларуская навука пра кнігу: набыткі і праблемы, [в:] Современные проблемы книжной культуры: основные тенденции и перспективы развития: материалы Международного научного семинара (Минск, 2-3 апреля 2014 г.), Минск-Москва 2014, с. 18-21; eadem, Гісторыя беларускай кнігі і кнігазнаўства: дасягненні і патрэбы, [в:] Беларуская кніга у кантэксие сусветнай кніжнай культуры, Мінск 2014, вып. 5, с. 44-63.

118 Т. А. Самойлюк, Православная книга в Беларуси, Минск 2005.

119 Н. Ю. Вайцехович, Медицинская учебная книга в системе высшего образования, Диссертация на соискание ученой степени кандидата педагогических наук, Минск 2012.

120 О. В. Токарь, Л. И. Петровичева, Разработка типологических признаков серийного издания художественной литературы, Минск 2003.

121 Т. А. Самойлюк, Функциональная сущңность и свойства религиозной книги, [в:] Матэрыялы Трэиіх Міжнародных Кнігазнаўчых чытанняў „Кніга Беларусі: Повязь часой” (Мінск, 16-17 верасня 2003 г.), Мінск 2005, с. 105-117; eadem, Религиозная книга как книговедческая категория: фукции и свойства, [в:] Беларуская кніга ў кантэксие сусветнай кніжнай культуры, Мінск 2017, вып. 7, с. 121-133.

122 Н. Ю. Вайцехович, Типологические черты и функииональные особенности учебной медииинской книги, [в:] Культура Беларусі і сусвет: агульнае і асаблівае: даклады, прачытаныя на ХХХІІІ выніковай навуковай канферэниьы аспірантаў БДУ культуры і мастацтвай (Мінск, 23-24 красавіка 2008 г.), Мінск 2008, с. 27-31; eadem, Функиии медииинской учебной книги в системе высшего профессионального образования, [в:] ІІІ Машеровские чтения: материаль республиканской научно-практической конференции студентов, аспирантов и молодых ученых (Витебск, 24-25 марта 2009 г.), Витебск 2009, с. 31-32.

123 Л. І. Доўнар, Сутнаснае прызначэнне кнігі імовы якз'яваўкультуры: ад замаиаванай інфармацыі да трансляцыьі і пераемнасиі ведай, [в:] Беларуская кніга ў кантэксие сусветнай кніжнай культуры, Мінск 2012, вып. 4, с. 32-48.

124 Л. И. Петровичева, Е. Н. Богданович, Функииональная сущңность книги, „Труды БГТУ”, Минск 2012, № 9, с. 84-88.

125 Е. Н. Богданович, Функиииональный подход в проиессе редакиионно-издательской подготовки учебной книги для высших учебных заведений, Автореферат диссертации на соискание ученой степени кандидата филологических наук, Москва 2008.

126 Е. Н. Богданович, Л. И. Петровичева, Вузовский учебник (основные признаки структурной модели), Минск 2004; eidem, Структурная модель вузовской учебной книги, „Труды БГТУ. Серия 9. Издательское дело и полиграфия" 2003, вып. 9, с. 30-34; Н. Ю. Вайцехович, Типологическая модель учебной медицинской книги, [в:] Беларуская культура ва уимовах глабалізачьі: матэрыялы навуковай 20 канферэниыі, прысвечанай 35-годдзю БДУКМ (Мінск, 3 снежня 2010 г.): $y 2$ m., т. 2, Мінск 2011, с. 79-83.

127 Л. И. Петровичева, Основные сочиально-психологические показатели, формирующче тип читателя, „Труды БГТУ. Серия 9. Издательское дело и полиграфия” 2002, вып. 10 , с. 19-23; Н. У. Клімянкова, Праблемы тыпалогіi чытача з пункту гледжання тэорыі чы-

ROCZNIKI BIBLIOTECZNE

ROK LXIII, 2019

(C) for this edition by CNS 
Компетентными авторами в области историографии и источниковедения истории белорусской книги и истории книговедения выступают Г. Голенченко ${ }^{128}$, Ю. Лабынцев ${ }^{129}$, Н. Николаев ${ }^{130}$, Д. Карев ${ }^{131}$, А. Груша ${ }^{132}$, В. Герасимов $^{133}$, Ю. Лаврик ${ }^{134}$, Л. Юревич ${ }^{135}$, С. Павлова ${ }^{136}$ и др.). Наметилось направление по переизданию историко-книговедческих источников (напр., факсимильное - В. Ластовского ${ }^{137}$, а также перевод на белорусский языкА. Богаткевича ${ }^{138}$ ).

В числе современных проектов по общей истории белорусской книги, исторически важных для развития науки о книге и книжной культуры в Беларуси - двухтомное научное издание Гісторыя беларускай кнігі $(2009,2011)$, появившееся в издательстве „Беларуская Энцыклапедыя” по инициативе и под общей редакцией доктора филологических наук Н. Николаева: Кніж-

тацккага развіщия. Акмеалагічная канщэпџья чытання ў чытачазнаўстве і бібліятэказнайстве, [в:] Н. У. Клімянкова, Сацыялогія и псіхалогія чытання, Мінск 2015, с. 116-126.

128 Г. Я. Галенчанка, Невядомыя і малавядомыя помнікі духоўнай спадчыны і культурных сувязей Беларусі XV-сярэдзіны XVII cm., Мінск 2008.

129 Ю. А. Лабынцев, Западнославянские скориноведческие исследования в XVIIIпервой половине XIX вв., [в:] Скарына і наш час: матэрыялы V Міжнароднай навуковай канферэнщы (Гомель, 14-15 кастрычніка 2011 г., ред. А. А. Станкевіч, Гомель 2011, с. 21-22.

130 М. В. Нікалаеў, Гісторыя кніжнай культуры Беларусі: праблемы і перспектывы даследаванняй, [в:] Беларуская кніга ў кантэксие сусветнай кніжнай культуры у 2 ч., ч. 1, Мінск 2006, вып. 1, с. 19-30.

131 Д. В. Карев, Исторические горизонты восточнославянской элиты княжества литовского и ее наследников XVI-нач. ХХ вв. (по материалам рукописных, архивных и книжных собраний Восточной Европы), [в:] Беларуская кніга ў кантэксие сусветнай кніжнай культуры, ч. 1, Мінск 2006, вып. 1, с. 129-136.

132 А. И. Груша, Документальная письменность Великого Княжества Литовского (конеи XIV-первая треть XVI в.), Минск 2015.

133 В. Герасімаў, Праект Вайсблюма: помнік кнігазнаўства і бібліятэчнай справы, [в:] Беларуская кніга ў кантэксие сусветнай кніжнай культуры, Мінск 2017, вып. 7, с. 162-193.

134 Ю. Лаўрык, Praeliminaria для вывучэння гісторыі габрэйскага і татарскага пісьменства на беларускіх землях. Частка I. Praeliminaria для вывучэння гісторыі габрэйскай кнігі, [в:] Беларуская кніга у кантэксие сусветнай кніжнай культуры, Мінск 2017, вып. 7, c. $193-262$.

135 Л. Юрэвіч, Эмігрант Франиыск Скарына, иі Апалогія, [в:] Бібліятэка Бацькаўшчыны кн. 25, Мінск 2015. См. также рецензию на данную книгу: Л. І. Доўнар, На шляху да набілітащыі эмігращыйнага скарыназнауствва „Запісы = Zаріsу” 2017, № 39, с. 500-506.

136 С. А. Павлова, Книга и чтение в жизни партизан Беларуси, Минск 2011.

137 В. Ластоўскі, Гісторыя беларускай (крыўскай) кнігі, факсимильное изд., Мінск 2012 (В. Ластоўскі, Гісторыя беларускай (крыўскай) кнігі: Спроба паясніщельнай кнігапісі ад канча Х да пачатку XIX стагоддзя, Коўна 1926).

138 А. В. Багаткевіч, Трактат аб Бібліяграфіi ўсеагульнай, пер. Л. І. Доўнар, [в:] Здабыткі: дакументальныя помнікі на Беларусі, Мінск 2016, вып. 19, с. 9-25; 2017, вып. 20, с. $8-24 ; 2018$, вып. 21 , с. $7-21$.

ROCZNIKI BIBLIOTECZNE

ROK LXIII, 2019

(C) for this edition by CNS 
ная культура Вялікага Княства Літоўскага $\left(\right.$ т. 1, 2009) ${ }^{139}$ и Кніжнасиьь новай Беларусі XIX-XXI cmcm. (т. 2, 2011) ${ }^{140}$. Подобная комплексная научная работа по истории книжной культуры появилась в Беларуси впервые. В 2012 г. вышло и учебное пособие Гісторыя беларускай кнігі (2012) ${ }^{141}$, в котором также впервые была предпринята потытка охватить все периоды развития белорусской книги от средневековья до современности (XI-XXI вв.), а кроме того были представлены основные этапы развития науки о книге в Беларуси. В 2017 г. на основе данного материала, доработанного и дополненного разделами о книгораспространении и искусстве книги, появилась еще одна, структурно расширенная, версия прочтения истории белорусской книги - Антология мудрости народа: 500 лет белорусского книгопечатания ${ }^{142}$.

Вышли в свет и два новых издания по истории библиотек Беларуси ${ }^{143}$. Первое - монография Н. Берёзкиной ${ }^{144}$ Библиотеки и распространение научных знаний в Беларуси $(X V I-X X \text { вв. })^{145}$, в которой на богатом фактическом материале рассматривается становление и развитие научных библиотек Беларуси, содержатся сведения о многих ученых, владельцах книжных собраний. К сожалению, объемный текст не оснащен вспомогательными указателями. Особенностью второго издания - Из истории в будущзее. Библиотеки Беларуси ${ }^{146}$ доктора педагогических наук, директора НББ Романа Мотульского, является включение основных вопросов зарождения и развития книжного дела в состав истории библиотечного дела Беларуси, которые в целом рассматриваются в контексте национальной и общеевропейской истории. Ряд материалов статей Р. Мотульского, посвященных истории би-

139 М. В. Нікалаеў, Кніжная культура Вялікага Княства Літоўскага, [в:] Гісторыя беларускай кнігі: у 2 m., т. 1, Мінск 2009.

140 М. В. Нікалаеў, Л. І. Доўнар, М. А. Лукоўская et al., Кніжнасиь новай Беларусі (XIXXXI cmcm.), [в:] Гісторыя беларускай кнігі: у 2 m., т. 2, ред. В. В. Антонаў, М. В. Нікалаеў, Мінск 2011.

141 Л. І. Доўнар, Гісторыя беларускай кнігі...; Т. Камусэла, [Рэцэнзія], Тамаш Камусэла, пер. А. Каскевіч-Сяргунчык, „Беларускі Гістарычны Агляд” 2015, т. 22, с. 337-342.

142 И. В. Войтов, Л. И. Довнар, Д. П. Зылевич et al., Антология мудрости народа: 500 лет белорусского книгопечатания, Минск 2017.

143 Первым и единственным учебником по истории библиотек Беларуси является следующее издание: М. И. Покало, История библиотечного дела в БССР, Минск 1986.

144 Н. Ю. Берёзкина - автор первого учебного пособия по истории книгопечатания в Беларуси, вышедшего в 1998 г., дополненного и переизданного в 2000 г.: Н. Ю. Бярозніка, Гісторыя кнігадрукавання Беларусі (XVI-пач. XX ст.), Мінск 2000.

145 Н. Ю. Берёзкина, Библиотеки и распространение научных знаний в Беларуси (XVI$X X$ вв.), ред. М. П. Костюк, А. А. Коваленя, Минск 2011; 2-е изд., испр. и доп., Минск 2013.

146 Р. С. Мотульский, Из истории в будущее. Библиотеки Беларуси: в 2 ч., ч. 1. IX-начало ХХ в., Минск 2011; idem, Библиотеки Беларуси в IX-начале XX в.: в контексте национальной и общеевропейской истории, Saarbrücken 2015; idem, Библиотеки Беларуси. Из прошлого в будущее, 1917-1991, Минск 2018. 
блиотечного дела Беларуси ${ }^{147}$, освещается с привлечением материалов по истории письменности и книгопечатания ${ }^{148}$.

Исторические формы развития носителей фиксированных знаний (рукописная книга, книгопечатание, цифровые коммуникации) стали основой методологического подхода к периодизации, представленной в новом учебном пособии Бібліяграфазнаўства. Гісторыя ${ }^{149}$ (2017), составленном библиографоведами Валентиной Саитовой, В. Леончиковым, Т. Кузьминич. Данное пособие состоит из следующих разделов: Бібліяграфія у рукапісны перыяд развіщия тэкставых камунікаџый (III тысячагоддзе да н. э.-XV ст.), Бібліяграфія у перыяд кнігадрукавання як асноуннага сродка фіксавання і распаўсюджання інфармаџылі (канеи XV-сярэдзіна XX ст.), Бібліяграфія ў перыяд станаўлення і развіция лічбавых камунікацый (канеи XX-пачатак XXI cm.) ${ }^{150}$.

Стремлением к комплексному подходу в области организации научных исследований книжной культуры характеризуется деятельность некоторых региональных центров, каким, например, является Брестская областная библиотека имени М. Горького и её тематическое издание Берасиейскія кнігазборы: праблемы і перспектывы даследавання ${ }^{151}$. Отметим, что впервые

147 См. персональный сайт Р. С. Мотульского: http://old.nlb.by/director/index.php?path=/ catalogue $/$ view-413\&menu_id=241

148 Например: Р. С. Мотульский, Книгопечатание и библиотечное дело в западных регионах Беларуси в 1921-1939 г2., [в:] Берасиейскія кнігазборы: праблемы і перспектывы даследавання: матэрыялы і даклады II Міжнароднай навукова-практычнай канфэрэниыі (Брэст, 31 мая-3 чэрвеня 2012 г.), Брэст 2013, с. 92-116; idem, Книгопечатание и книжные собрания греко-католических монастырей на территории Беларуси, [в:] Славянское книгопечатание и культура книги: материаль Международной научной конференции (Минск, 16-18 сентября 2009 г.), ред. Л. А. Авгуль et al., Москва 2009, с. 56-65; idem, Книгопроизводство и книгораспространение в Беларуси в конце XVIII-начале XX века, [в:] Книга в пространстве культуры, прилож. к журналу „Библиотековедение” 2012, № 1, с. 34-46.

149 Бібліяграфазнаўства. Гісторыя...

150 См.: Н. А. Лейко, Т. А. Самайлюк, Гісторыя сусветнай $і$ айчыннай бібліяграфiі, [рец.] В. І. Саітава, В. Е. Лявончыкаў, Бібліяграфазнаўства. Гісторыя, рэд. Т. В. Кузьмініч, Мінск 2017, [в:] Беларуская кніга у кантэксие сусветнай кніжнай культуры, Мінск 2017, вып. 7, с. 309-312.

151 Берасиейскія кнігазборы: матэрыялы міжнароднай навукова-практычнай канферэнщылі „Берасиейскія кнігазборы: праблемы і перспектывы даследавання” (Брэст, 3031 кастрычніка 2008 г.), сост. А. М. Мяснянкіна, Т. С. Кавенька, рэд. М. В. Нікалаева, Брэст 2010; Берасиейскія кнігазборы: праблемы і перспектывы даследавання: матэрыялы і даклады II Міжнароднай навукова-практычнай канферэниыы (Брэст, 31 мая-3 чэрвеня 2012 г.), уклад. А. М. Мяснянкіна, Т. С. Кавенька, рэд. М. В. Нікалаева, Брэст 2013; Берасцейскія кнігазборы. Брэсикая Біблія - унікальны помнік культуры XVI стагоддзя: да 450-годдзя выдання: матэрыялы і даклады міжнароднага Круглага стала (Брэст, 29 мая-31 мая 2013 г.), сост. А. М. Мяснянкіна, Т. С. Кавенька, рэд. М. В. Нікалаева, Брэст 2014; Берасиейскія кнігазборы: праблемы і перспектывы даследавання: матэрыялы і даклады III Міжнароднай навукова-практычнай канферэнщыі (Брэст, 22-25 верасня 2015 г.), уклад. А. М. Мяснянкіна, рэд. М. В. Нікалаева, Мінск 2016.

ROCZNIKI BIBLIOTECZNE

ROK LXIII, 2019

(C) for this edition by CNS 
в региональном книговедении Беларуси книга здесь представлена в ретроспективе и перспективе создания, бытования, распространения, хранения и сохранности; в контексте истории и культуры определенного региона. Программные направления научного проекта Берасиейскія кнігазборы отражены в предисловии к первому изданию материалов конференции (2008). Вместе с тем, что значительная часть опубликованных материалов имеет краеведческий характер, отличились Берасцейскія кнігазборы и несколькими публикациями, в которых авторы представляют теоретико-методологические проблемы изучения регионального книговедения ${ }^{152}$. Среди работ, выполненных историками-краеведами, выделяется недавно опубликованное библиографическое издание Михаила Бавтовича Кнігадрук у Полащку, представляющее результаты источниковедческо-библиографических поисков и находок автора о книгопечатании в Полоцке в 1774-1829 гг. ${ }^{153}$

Наибольшее отражение в контексте рассмотрения книговедческих проблем получил региональный аспект в монографи Л. Довнар Кніжная справа у Мінску (канец XVIII-пачатак XX стагоддзя) (2015) ${ }^{154}$, раскрывающей основные тенденции и закономерности развития книгоиздания, книгопечатания, книжной торговли и библиотечных книжных собраний губернского города и его связей со столицами (Петербургом, Варшавой, Вильней). Важной составляющей издания стал каталог минских разноязычных изданий 1622-1917 гг. Системный подход характерен и другим исследованиям, например, по изучению латинографических ${ }^{155}$ и латиноязычных изданий ${ }^{156}$,

152 См. статьи К. Мигоня и Л. Довнар в издании: Берасиейскія кнігазборы: праблемы і перспектывы даследавання: матэрыялы і даклады ІІ Міжнароднай навукова-практычнай канферэнщыі (Брэст, 31 мая-3 чэрвеня 2012 г.)..., с. 13-21, 65-80.

153 М. Баўтовіч, Кнігадрук ў Полачку (1774-1829): бібліяграфічнае выданне, Полацак 2018.

154 Л. І. Доўнар, Кніжная справа Мінска як аб’ект вывучэння ў кантэксие кнігазнаўчых даследаванняў: уступ, [в:] еadem, Кніжная справа у Мінску (канеи XVIII-пачатак XX стагоддзя), Мінск 2015; К. Мигонь, [рец.], „Веснік Беларускага дзяржаўнага ўніверсітэта культуры і мастацтваў” 2016, № 1, с. 249-252; O. Janonis, [рец.] Svarus įnašas i Baltarusijos regioninę knygotyra, „Knygotyra” 2017, т. 69, c. 264-266.

155 T. І. Рошчына, Беларускія старадрукі XVI-XVII стст. лачінскім шрыфтам у польскіх сховішчах, [в:] Матэрыялы Х Міжнародных кнігазнаўчых чытанняў „Кніжная культура Беларусі XVI-сярэдзіны XVII ст.: да 440-годдзя выдавеикай дзейнасиі Мамонічай” (Мінск, 17-18 красавіка 2014 г.), Мінск 2014, с. 140-144.

156 Н. С. Саверчанка, Заходнееурапейскі кніжны друк і яго значэнне для Беларусі, [в:] Здабыткі: дакументальныя помнікі на Беларусі, Мінск 2007, вып. 9, с. 40-47; eadem, 3aходнееурапейскія старадрукі другой паловы XVI cm. у фондах Наџыянальнай бібліятэкі Беларусі, [в:] Здабыткі: дакументальныя помнікі на Беларусі, Мінск 2004, вып. 6, с. 100-113; Т. М. Абухоўская, I. А. Сынкова, Калекцыя лаџінамоўных выданняў XV-XVII cтст. аб Беларусі ў фондах Цэнтральнай навуковай бібліятэкі Наџыянальнай акадэміі навук Беларусі, [в:] Беларуская кніга у кантэксие сусветнай кніжнай культуры у 2 ч., ч. 1, Мінск 2006, вып. 1,

ROCZNIKI BIBLIOTECZNE

ROK LXIII, 2019

(C) for this edition by CNS 
арабографической книжной продукции Беларуси ${ }^{157}$, дополнением к которым служат работы по искусству книги ${ }^{158}$.

Определенным стимулом развития и расширения научной работы в области книжной культуры Беларуси является проектная деятельность. Стоит назвать научно-исследовательские проекты, результаты которых составили компетентную основу для осуществления дальнейших планов, связанных с юбилееми 490-летия, а также 500-летия белорусского книгопечатания: в БГУКИ - это Кніжная культура Беларусі: гісторыка-тэарэтычны аспект $(2006-2010)^{159}$; в ЦНБ НАНБ - Книжная культура Росии и Беларуси в контексте историко-культурного взаимодействия (2010-2012) ${ }^{160}$, Книжная

с. 202-208; І. А. Сынкова, Інкунабулы у фондах ЦНБ НАН Беларусі, „Беларускі археаграфічны штогоднік" 2005, вып. 6, с. 85-94.

157 А. І. Цітавец, Арабаграфічныя рукапісы канца XVII-першай палавіны XX cm. крыніџы для вывучэння духоўнай культуры татараў Беларусі, Аўтарэферат дысертацыі на суісканне вучонай ступені кандыдата гістарычных навук, Мінск 2009; Рукапісы татарай Беларусі канияа XVIII-пачатку XX стагоддзя з дзяржаўных і грамадскіх кнігазбораў краіны: каталог, уклад. М. У. Тарэлка, А. І. Цітавец, Мінск 2011; Рукапісы татараў Беларусі каниа XVIII-пачатку XXI стагоддзя з дзяржаўных і грамадскіх кнігазбораў краіны: каталог, уклад. М. У. Тарэлка, Мінск 2015; Л. И. Станкевич, Рукописные памятники мусульманской книжности в государственных коллекииях Беларуси: состояние и проблемы сохранения, [в:] Первая Международная научно-практическая конференщия: «Исследования, консервация и реставрачия рукописных и печатных памятников Востока» (Москва, 17-19 апреля 2007 г.), сост. Л. И. Станкевич, И. А. Сынкова, М. В. Тарелко, Москва 2007, с. 192-197; I. А. Сынкова, М. У. Тарэлка, Пераклады Бібліі XVI-XVII cmст. у літаратуры літоўскіх mamapay̆, [в:] Bibel, Liturgie und Frömmigkeit in der Slavia Byzantina. Festgabe für Hans Rothe zum Geburtstag, herausgegeben von D. Christians, D. Stern, V. S. Tomelleri, München-Berlin 2009, с. 82-93; I. Сынкова, Рукапіс з Музея начьлянальных культур Іўя у святле неарабскаграфічнай рукапіснай спадчыны татараў былога Вялікага Княства Літойскага, „Slavistica Vilnensis" 2015, т. 60, c. 177-187.

158 С. И. Леонтьева, Искусство рукописной книги Ветки XVIII-начала ХХ века, Автореферат диссертации на соискание ученой степени кандидата искусствоведения, Минск 2009; Книжная культура. Ветка, сост. С. И. Леонтьева, Г. Г. Нечаева, Минск 2013; І. А. Сынкова, Мастацтва уссходняй аправы: беларускія калекиьі у кантэксие мусульнаскай традыйыi, [в:] Беларуская кніга у кантэксие сусветнай кніжнай культуры, Мінск 2011, вып. 3, с. 307-322; И. А. Сынкова, Западноевропейские переплеты XVI в. в фондах Центральной научной библиотеки им. Я. Коласа НАН Беларуси, [в:] Книга источник культуры. Проблемы и методы исследования: материалы Международной научной конференции (Минск, 25-27 ноября 2008 г.), Москва-Минск 2008, с. 328-336.

159 Л. И. Довнар, Т. А. Самойлюк, Книжная культура Беларуси: кониептуальные основы и пути реализачии научного проекта Белорусского государственного университета культуры и искусств, [в:] Книга источник культуры..., с. 123-131.

160 Книжная культура России и Беларуси в контексте историко-культурного взаимодействия, отв. ред. В. И. Васильев, Минск-Москва 2013; Книжная культура России и Беларуси в контексте историко-культурного взаимодействия: в 2 кн., отв. ред. В. И. Васильев, Москва-Минск 2015.

ROCZNIKI BIBLIOTECZNE

ROK LXIII, 2019

(C) for this edition by CNS 
культура в контексте инновационного развития общества (2014-2016) ${ }^{161}$, в НББ - Библиотеки и книжная культура Беларуси XI-XXI вв. в рамках Государственной программы Культура на 2011-2015 гг. ${ }^{162}$, благодаря которой был развернут и следующий проект Франциск Скорина - белорусский и восточнославянский первопечатник (2011-2017), программа Скарыніяна ${ }^{163}$. Одним из масштабных заданий программы Скарыніяна, реализованным НББ при финансовой поддержке банка БелВЭБ в течении 2013-2017 гг., стал международный научно-исследовательский и издательский проект по воссозданию книжного наследия первопечатника - Кніжная спадчына Франщыска Скарыны ${ }^{164}$. Факсимильное переиздание книг Ф. Скорины составило 20 томов (Біблія - т. 1-18, Малая падарожная кніжка — т. 19, ч. 1-2, Апостал т. 20) и еще один том - научные комментарии ${ }^{165}$, в котором раскрываются пути возвращения книжного наследия Франциска Скорины в Беларусь, показывается опыт его введения в научный и общественный оборот, достижения в факсимильном и виртуальном воспроизведении.

500-летию белорусского книгопечатания было посвящено ряд международных научных конференций, наиболее значимые - организованные крупнейшими библиотеками Беларуси: Библиотекой Академии наук Берковские чтения ${ }^{166}$ и семинар Франииск Скорина - личность, деятельность, наследие, современные образы ${ }^{167}$; Национальной библиотекой Бела-

161 Книжная культура в контексте инновационного развития общества, отв. ред. В. И. Васильев, Минск-Москва 2017.

162 Л. Г. Кирюхина, А. А. Суша, М. Г. Алейник, Перспективы исследования истории и современного состояния библиотечного дела и книжной культуры Беларуси в рамках Государственной программь „Культура” на 2011-2015 г2., [в:] Материаль VI Международных книговедческих чтений „Библиотеки в формировании инновационной средь для развития науки, образования и бизнеса" (Минск, 27-29 октября 2010 г.), сост. Л. Г. Кирюхина, Минск 2010, с. 128-133.

163 Г. В. Киреева, Программа „Скориниана”: задачи и перспективы реализации, [в:] Матэрыялы IX Міжнародных кнігазнаўчых Чытанняў „Статут Вялікага Княства Літоўскага ў гісторыі культуры Беларусі” (Мінск, 18-19 красавіка 2013 г.), уклад. Т. А. Сапега, А. А. Суша, Мінск 2013, с. 140-146.

164 НББ осуществила также беспрецедентный шаг по бесплатному и широкому распространению комплекта факсимильных изданий всех книг Ф. Скорины по библиотекам Беларуси и крупнейшим библиотекам зарубежных стран.

165 Кніжная спадчына Франиыска Скарыны. Вяртанне = Книжное наследие Франичиска Скорины. Возвращение = Book heritage of Francysk Skaryna. Returning, рэд. А. А. Суша, Мінск 2017.

166 Берковские чтения - 2017. Книжная культура в контексте международных контактов: материаль IV Международной научной конференции (Полоцк, 24-25 мая 2017 г.), сост. Л. А. Авгуль, Д. Н. Бакун, Минск-Москва 2017.

167 Франциск Скорина - личность, деятельность, наследие, современные образы: материаль Международного научного семинара (Полоц̧к, 24 мая 2017 г.), сост. Л. А. Авгуль, Д. Н. Бакун, Минск-Москва 2017. (Современные проблемы книжной культуры). 
руси - Международный конгресс 500 гадоў беларускага кнігадрукавання и XIII Міжнародныл кнігазнаўчыл чытанні ${ }^{168}$. Вышли в свет обновленная энциклопедия Францыск Скарына (2017) ${ }^{169}$, научно-популярное издание Сусветная спадчьна Францыьска Скарыны (2017) ${ }^{170}$, посвященное описанию сохраненных книг Ф. Скорины в библиотеках разных стран мира, инициированные НББ. К юбилею белорусского книгопечатания был издан не один десяток книг и статей, среди которых и ценные источниковедческие материалы исследователей из белорусского зарубежья - Леона Юревича (США), под названием Эмігрант Францыск Скарына, изі Апалогія ${ }^{171}$. Таким образом, взаимодействие научного и практического - издательского — направлений, за основу разработки которых был взят инструментарий промоции книжного наследия, несомненно, дало свои плоды.

Белорусское книговедение, его наследие и исследовательский опыт, владеющие давольно широким и разнообразным материалом: от эмпирического до глубоко осознанного, от собственно национального до транскультурного и наооборот, отражают состояние и дальнейшие направления развития науки о книге в Беларуси как в историческом, так и теоретико-методологическом аспектах, что позволяет говорить и о дальнейшем формировании белорусской книговедческой школы, которой характерно: 1) использование в методологии научных исследований междисциплинарного, компаративного подхода, научного взаимодействия с общими и частными (специальными) направлениями философии ${ }^{172}$, культурологии ${ }^{173}$, библиотековедения и биб-

168 Матэрыялы міжнароднага кангрэса «500 гадоўбеларускага кнігадрукавання». ХІІІ Міжнародныя кнігазнаўчыл чытанні (Мінск, 14-15 верасня 2017 г.). У 2 ч., сост. А. А. Суша, Мінск 2017.

169 Францыьск Скарына: энщылклапедыя, гл. ред. У. У. Андрыевіч, Мінск 2017. Издание (в отличие от предыдущих энциклопедий, посвященных Ф. Скорине) дополнено статьями „Кнігазнаўства” (с. 298-299) и „Кніжная культура” (с. 299), автором которых является А. Суша.

170 Сусветная спадчьна Францыска Скарыны = Всемирное наследие Франциска Скоpинь $=$ World Heritage of Francysk Skaryna, сост. А. А. Суша, Мінск 2017.

171 Л. Юрэвіч, Эмігрант Францьыск Скарына, ичі Апалогія, Мінск, 2015. Рец. на кн.: Л. І. Доўнар, На шляху да набілітацыьі эміграцуыйнага скарыназнауства, „Запісы = Zapisy” 2017, № 39, c. 500-506.

172 М. І. Крукоўскі, Філасофія культуры: уводзіны у тэарэтылную культуралогію, Мінск 2000; М. І. Крукоўскі, Кніга і яе месиза ў сістэме культуры, [в:] Беларуская кніга у кантэксие сусветнай кніжнай культуры у 2 ч., ч. 2, Мінск 2006, вып. 1, с. 52-55; М. А. Можейко, Книга как культурный символ, [в:] Беларуская кніга у кантэксце сусветнай кніжнай культуры у 2 ч., ч. 2, Мінск 2006, вып. 1, с. 49-52; М. А. Можейко, Постмодернистское переосмысление феномена книги: внегутенберговское бытие книжной культуры, [в:] Беларуская кніга ў кантэксие сусветнай кніжнай культуры, Мінск 2011, вып. 3, с. 39-68.

173 Ю. Г. Болотова, Книга как соичикультурный феномен в контексте современной белорусской культуры, Диссертация на соискание ученой степени кандидата культурологии, Минск 1999; А. И. Смолик, „Массовая литература” как сочиально-культурное явление, [в:]

ROCZNIKI BIBLIOTECZNE

ROK LXIII, 2019

(C) for this edition by CNS 
лиографоведения ${ }^{174}$, документологии $\left.{ }^{175} ; 2\right)$ ориентация в исследованиях на аксиологический подход, феноменологию книги, концентрация внимания на проблемах сущностного порядка, связанных с познанием книги в книжной культуре, 3) развитие международных связей в области изучения книжного наследия, обмен научным опытом ${ }^{176}$, активизация процессов глокализации белорусской науки о книге в международном научном сообществе.

\section{БИБЛИОГРАФИЯ}

Aleksandrovič S. Ch., Knihaznaǔstva, [v:] Bielaruskaja Savieckaja Encyklapiedyja, t. 6, Minsk 1972.

Bahatkevič A. V., Traktat ab Biblijahrafii ǔseahuĺnaj, per. L. I. Doǔnar, [v:] Zdabytki: dakumientaínyja pomniki na Bielarusi, Minsk 2016, vyp. 19, s. 9-25; 2017, vyp. 20, s. 8-24; 2018, vyp. 21, s. 7-21.

Belovickaya A. A., Knigovedenie. Obshchee knigovedenie, Moskva 2007.

Berkov P. N., Kniga v poèzii Simeona Polockogo, [v:] Literatura i obshchestvennaya mysl' Drevnej Rusi: k 80-letiyu so dnya rozhdeniya chlena-korrespondenta AN SSSR V. P. AdrianovojPeretc, Leningrad 1969.

Bolotova Ju. G., Kniga kak sociokul'turnyj fenomen v kontekste sovremennoj belorusskoj kul'tury, Dissertaciya na soiskanie uchenoj stepeni kandidata kul'turologii, Minsk 1999

Dianova V. M., Transkul'turaciya kak strategiya izucheniya kul'turnogo naslediya: belorusskie landshafty, [v:] Pieršy mižnarodny kanhres bielaruskaj kultury (Minsk, 5-6 maja 2016 h.), red. A. I. Lakotka, Minsk 2016.

Doǔnar L. I., ,,Bielaruskaja kniha ǔ kantekscie susvietnaj knižnaj kuĺtury” ǔ asobach i pracach, [v:] Materyjaly XII Mižnarodnych knihaznaǔčych čytanniaǔ „Knižnaja kultura Bielarusi: pogliad praz stahoddzi” (7-8 krasavika 2016 h.), sklad. T. A. Sapiega, A. A. Suša, Minsk 2016.

Doǔnar L. I., Bielaruskaja navuka pra knihu ǔ kantekscie piersanaĺnaha knihaznaǔstva, „Viesnik Bielaruskaha dziaržaǔnaha ǔniviersiteta kuĺtury i mastactvaǔ” 2014, № 1.

Беларуская кніга у кантэксие сусветнай кніжнай культуры у 2 ч., ч. 2, Мінск 2006, вып. 1, с. 89-96; А. А. Павільч, Станаўленне кампаратыўных ведаў у кніжнай культуры Беларусі, [в:] Беларуская кніга ў кантэксие сусветнай кніжнай культуры, Мінск 2011, вып. 3, с. 68-82.

174 Научная школа в области педагогики „Библиотековедение, библиографоведение и книговедение”, ред. Л. И. Довнар, Минск 2014; В. А. Касап, В. Е. Леончиков, Ж. Л. Романова, Теоретико-методологические вопросы библиотековедения, библиографоведения и книговедения: учебно-методический комплекс, Минск 2017.

175 В. А. Касап, К вопросу формирования и изменения книговедческих парадигм, [в:] Берковские чтения. Книжная культура в контексте международных контактов: материаль Междунар. науч. конф. (Минск, 16-17 мая 2013 г.), Минск-Москва 2013, с. 170-172; Ю. Нестеренко, Документологический подход к соотнесению понятий книги, документа, издания и произведения, [в:] Берковские чтения. Книжная культура в контексте международных контактов: материаль Междунар. науч. конф. (Минск, 25-26 мая 2011 г.), Минск-Москва 2011, с. 249-254; idem, Коррелячия понятий текста и произведения в междисииплинарном поле, [в:] Беларуская кніга у кантэксие сусветнай кніжнай культуры, Мінск 2014, вып. 5, с. 64-81.

176 Л. И. Довнар, Открытые вопросы белорусского книговедения в контексте транслятологического опыта, „Бібліотечний вісник” 2017, № 4, с. 42-48. 
Doǔnar L. I., Bielaruskaja navuka pra knihu: nabytki i prabliemy, [v:] Sovremennye problemy knizhnoj kul'tury: osnovnue tendencii i perspektivy razvitiya: materialy Mezhdunarodnogo nauchnogo seminara (Minsk, 2-3 aprelya 2014 g.), Minsk-Moskva 2014.

Doǔnar L. I., Francysk Skaryna i vytoki knihaznaǔčych viedaŭ Bielarusi, [v:] Francisk Skorinalichnost', deyatel'nost', nasledie, sovremennye obrazy: materialy Mezhdunarodnogo nauchnogo seminara (Polock, 24 maya 2017 g.), sost. L. A. Avgul', D. N. Bakun, MinskMoskva 2017.

Doǔnar L. I., Historyja bielaruskaj knihi i knihaznaǔstva: dasiahnienni i patreby, [v:] Bielaruskaja kniha ǔ kantekscie susvietnaj knižnaj kultury, Minsk 2014, vyp. 5.

Doǔnar L. I., Historyja bielaruskaj knihi: vučebny dapamožnik, Minsk 2012.

Doǔnar L. I., Kniha i dakument u kantekscie kahnityǔna-aksijalahičnaha padychodu, „Viesnik Bielaruskaha dziaržaǔnaha ǔniviersiteta kultury i mastactvaǔ” 2015, № 1.

Doǔnar L. I., Knihaznaǔčaja dumka ǔ epochu Francyska Skaryny: interpretacyi pavodlie knihi „Iucunda familia librorum. Humaniści renesansowi w świecie ksiązki” Janusza Gruchały, „Bielaruskaja kniha ǔ kantekscie susvietnaj knižnaj kuĺtury”, Minsk 2017, vyp. 7.

Doǔnar L. I., Knihaznaǔčyja viedy dlia biblijatekaraǔ ad Iaachima Lialievielia, [v:] Materyjaly XIV Mižnarodnych knihaznaǔčyh čytanniaŭ, prymierkavanych da 400-hoddzia pieršaha „Bukvara”, Minsk, 26-27 krasavika 2018 h., сост. T. A. Sapiega, A. A. Suša, Minsk 2018.

Doǔnar L. I., Knižnaja kulttura Bielarusi pamiž kahnityǔnaj strategijaj i taktykaj instrumientalizacyi, [v:] Skorinovskie chteniya 2016: kniga kak fenomen kul'tury, iskusstva, tekhnologii: materialy II Mezhdunarodnogo foruma (Minsk, 6-7 sentyabrya 2016 g.), Minsk 2016.

Doǔnar L. İ., Knižnaja sprava Minska jak abjiekt vyvučennia ǔ kantekscie knihaznaǔčych dasliedavanniaŭ: ustup, [v:] eadem, Knižnaja sprava ǔ Minsku (kaniec XVIII-pačatak XX stahoddzia), Minsk 2015.

Doǔnar L. I., Na šliachu da nabilitacyi emihracyjnaha skarynaznaǔstva, „Zapìsy = Zapisy” 2017, № 39.

Doǔnar L. I., Prabliemnaje polie bielaruskaj knihaznaǔčaj navuki i adukacyi, [v:] Bielaruskaja kniha ǔ kantekscie susvetnaj knižnaj kultury, č. 2, Minsk 2006, vyp. 1.

Doǔnar L. I., Regijanalnyja dasliedavanni historyi knihi ǔ Bielarusi: da pytannia ab rehijanaĺnym knihaznaǔstvie, [v:] Materialy VII Meždunarodnyh knigovedčeskih čtenij „,Biblioteki i politika otkrytogo dostupa k informacii i znaniyam” (Minsk, 10-11 noyabrya 2011g.), sost. L. G. Kiriuhina, Minsk 2011.

Doǔnar L. I., Sutnasnaie pryznačennie knihi i movy jak zjava ǔ kultury: ad zamacavanaj infarmacyi da transliacyi i pierajemnasci viedaǔ, „Bielaruskaja kniga ǔ kantekscie susvietnaj knižnaj kultury: vyvučennie i zachavannie", Minsk 2012, vyp. 4.

Doǔnar L. I., U horadzie maim — takim macoǔnym — adzin ja byǔ!, [v:] „Bielaruskaja kniga ǔ kantekscie susvietnaj knižnaj kuĺtury", Minsk 2011, vyp. 3.

Doǔnar L. I., Bielaruskaja navuka pra knihu ǔ kantekscie piersanaĺnaha knihaznaǔstva, „Viesnik Bielaruskaha dziaržaǔnaha ǔniviersiteta kuĺtury i mastactvaŭ” 2014, № 1.

Dovnar L. I., Do i posle Vaclava Lastovskogo: belorusskaya nauka o knige v kontekste personal'nogo knigovedeniya, „Knygotyra” 2013, t. 60.

Dovnar L. I., Belorusskoe knigovedenie i nacional'noe vozrozhdenie 1920-h godov, „Knygotyra” 2007, t. 48.

Dovnar L. I., Knigovedcheskoe znanie i belorusskaya bibliografiya: istochniki i orientiry, [v:] Trudy Mezhdunarodnogo bibliograficheskogo kongressa (Sankt-Peterburg, 21-23 sentyabrya 2010 g.), ch. 3, Sankt-Peterburg 2012.

Dovnar L. I., Knizhnaya kul'tura kak filosofsko-kul'turologicheskaya kategoriya bibliologii (k postanovke problemy), [v:] Nauka o knige. Tradicii i innovacii: materialy Dvenadcatoj Mezhdunarodnoj konferencii po problemam knigovedeniya (Moskva, 28-30 aprelya 2009 g.): K 50-letiyu sbornika „Kniga. Issledovaniya i materialy”, ch. 1, Moskva 2009.

ROCZNIKI BIBLIOTECZNE

ROK LXIII, 2019

(C) for this edition by CNS 
Dovnar L. I., O roli lichnosti v razvitii nauki o knige, ili Shtudii Kshishtofa Migonya, [v:] Berkovskie chteniya. Knizhnaya kul'tura v kontekste mezhdunarodnyh kontaktov: materialy Mezhdunarodnoj nauchnoj konferencii (Minsk, 25-26 maya 2011 g.), Minsk-Moskva 2011.

Dovnar L. I., Otkrytye voprosy belorusskogo knigovedeniya v kontekste translyatologicheskogo opyta, „Bìblìotečnij vìsnik” 2017, № 4.

Dovnar L. I., Samojlyuk T. A., Knizhnaya kul'tura Belarusi: konceptual'nye osnovy i puti realizacii nauchnogo proekta Belorusskogo gosudarstvennogo universiteta kul'tury i iskusstv, [v:] Kniga - istochnik kul'tury: problemy i metody issledovaniya: materialy Mezhdunar. nauch. konf. (Minsk, 25-27 noyabrya 2008 g.), Moskva 2008.

Dovnar L. I., Vozniknovenie i razvitie nauki o knige v Belarusi: istoki i perspektivy vo vzaimosvyazi, [v:] Fyodorovskie chteniya, 2011, Moskva 2012.

Dovnar L., Belorusskaya kniga kak universum nacional'noj kul'tury, „Knygotyra” 2010, t. 54.

Dovnar L., Belorusskoe knigovedenie i nacional'noe vozrozhdenie 1920-h godov, „Knygotyra” 2007, t. 48.

Dovnar L., Kniga i dokument: „,cena” voprosa „Knygotyra” 2011, t. 57.

Hierasimaǔ V. M., Da prabliemy histaryjahrafii knihaznaǔstva bielaruskaha zamiežža, [v:] Bielaruskaja kniha ǔ kantekscie susvietnaj knižnaj kultury, č. 2, Minsk 2006, vyp. 1.

Hierasimaǔ V. M., Druk Bielarusi 1941-1945 hh. u fondach Prezidenckaj biblijateki Respubliki Bielaruś jak abjekt biblijahrafičnaj i kulturnaj identyfikacyi, [v:] Duchoǔnyja asnovy sučasnaj kultury: prabliemy zachavannia kulturnaj spadčyny: XVI Mižnarodnyja Kiryla-Miafodzijeǔskija čytanni, prysviečanyja Dniam slavianskaha piśmienstva i kultury (Minsk, 26-28 maja 2010 h.), t. 1, Minsk 2011.

Hierasimaǔ V. M., Knihaznaǔstva, [v:] Encyklapiedyja historyi Bielarusi, t. 4, Minsk 1997.

Golenchenko G. Ja., Istoriya belorusskogo knigopechataniya XVI-XVIII (kirillovskogo), Avtoreferat dissertacii na soiskanie uchenoj stepeni kandidata istoricheskih nauk, Moskva 1965.

Iz bumag V. U. Lastovskogo, podgotovka i publikaciya teksta N. A. Popkovoj, [v:] Bielaruskaja kniha ǔ kantekscie susvietnaj knižnaj kuĺtury, Minsk 2011, vyp. 3.

Jurevič L., Emigrant Francysk Skaryna, ci Apalogija, Minsk, 2015 (Biblijateka Baćkaǔščyny; kn. 25).

Karotki U. H., Bielaruskija pradmovy i pasliasloǔi druhoj palaviny XVI-XVII st., [v:] Pradmovy i pasliasloǔi Francyska Skaryny, Minsk 1991.

Kasap V. A., K voprosu formirovaniya i izmeneniya knigovedcheskih paradigm, [v:] Berkovskie chteniya. Knizhnaya kul'tura v kontekste mezhdunarodnyh kontaktov: materialy Mezhdunar. nauch. konf. (Minsk, 16-17 maya 2013 g.), Minsk-Moskva 2013.

Kasap V. A., Knihaznaǔčyja dasliedavanni ǔ Bielaruskim dziaržaǔnym univiersitecie kuĺtury i mastactvaŭ, [v:] Bielaruskaja kniha ǔ kantekscie susvietnaj knižnaj kultury, Minsk 2008, vyp. 2.

Kireeva G. V., Programma ,Skoriniana”: zadachi i perspektivy realizacii, [v:] Materyjaly IX Mižnarodnyh knihaznaǔcych Čytanniaŭ ,, Statut Vialikaha Kniastva Litoǔskaha ǔ historyi kultury Bielarusi” (Minsk, 18-19 krasavika 2013 h.), sklad. T. A. Sapiega, A. A. Suša, Minsk 2013.

Knizhnaya kul'tura $v$ kontekste innovacionnogo razvitiya obshchestva, otvet. red. V. I. Vasil'ev, Moskva 2017.

Nikolaev N. V., Knizhnaya kul'tura Velikogo Knyazhestva Litovskogo, Avtoreferat dissertacii na soiskanie uchenoj stepeni doktora filologicheskih nauk, Sankt-Peterburg 1997.

Knižnasć novaj Bielarusi (XIX-XXI stst.), M. V. Nikalajeǔ, L. I. Doǔnar, M. A. Lukoǔskaja, R. S. Matuĺski, Minsk 2011 („Hìstoryja bielaruskaj knihi”, t. 2).

Koǔkeí L., Prabliemy dasliedavannia historyi čytannia ǔ Bielarusi ǔ XIX st., [v:] Bielaruskaja kniha ǔ kantekscie susvietnaj knižnaj kultury, Minsk 2015, vyp. 6.

Koval'čuk G., Rozvitok teorï knigoznavstva na sučasnomu etapi, „Bìblìotečnij vìsnik” 2009, № 5.

Krukoǔskì M. I., Filasofija kultury: uvodziny ǔ tearetyčnuju kuĺturalogiju, Minsk 2000.

Krukoǔskì M. I., Kniha i jaje miesca ǔ sistemie kultury, [v:] Bielaruskaja kniha ǔ kantekscie susvietnaj knižnaj kultury, č. 2, Minsk, vyp. 1.

ROCZNIKI BIBLIOTECZNE

ROK LXIII, 2019

(C) for this edition by CNS 
Kuźminič T. V., Ivanova A. V., Nacyjanaĺnaja biblijahrafija izachavannie knižnaj spadčyny Bielarusi, [v:] Materyjaly mižnarodnaha kanhresa „500 hadoǔ bielaruskaha knihadrukavannia”. XIII Mižnarodnyja knigihaznaǔčyja čytanni (Minsk, 14-15 vierasnia 2017 h.), č. 1, Minsk 2017.

Labyncev Yu. A., Mezhdunarodnaya slavyanovedcheskaya programma ,Istoriya knizhnoj kul'tury Podlyash'ya": (tekst dokl. na Mezhdunar. cerkovno-nauch. konf., posvyashch. 1000-letiyu Pravosl. cerkvi na Belarusi, 25 sent. 1992 g.), Minsk 1992.

Labyncev Yu. A., Zapadnoslavyanskie skorinovedcheskie issledovaniya $v$ XVIII-pervoj polovine XIX vv., [v:] Skaryna i naš čas: materyjaly V Mižnarodnaj navukovaj kanfierencyi (Gomel, 14-15 kastryčnika 2011 h., red. A. A. Stankievič et al., Gomeĺ 2011.

Labyncev Yu., Shchavinskaya L., Bibliologicheskie issledovaniya professora Mihaila Bobrovskogo i nasledie Franciska Skoriny, [v:] Francisk Skorina - lichnost', deyatel'nost', nasledie, sovremennye obrazy, sost. L. A. Avgul', D. N. Bakun, Minsk-Moskva 2017.

Lastoǔskì V., Historyja bielaruskaj (kryǔskaj) knihi, faksim. vyd., Minsk 2012 (Lastoǔski V., Historyja bielaruskaj (kryǔskaj) knihi: Sproba pajaśnicielnaj knihopisi ad kanca X da pačatku XIX stahoddzia, Koŭna 1926).

Laǔryk Ju., Histaryčnaje knihaznaǔstva jak samastojnaja navuka: da pastanoǔki prabliemy, [v:] Bielaruskaja kniha ǔ kantekscie susvietnaj knižnaj kultury, vyp. 5, Minsk 2014.

Laǔryk Ju., Najdaǔnejšyja bielaruskija knižnicy, „Rodnae slova” 2006, № 2, 4.

Laŭryk Ju., Praeliminaria dlja vyvučennia historyi habrejskaha i tatarskaha piśmienstva na bielaruskich ziemliach. Častka I. Praeliminaria dlia vyvučennia historyi habrejskaj knihi, [v:] Bielaruskaja kniha ǔ kantekscie susvietnaj knižnaj kultury, Minsk 2017, vyp. 7.

Liavončykaǔ V. E., Bielaruskaja kniha: padychody da vyznačennia zmestu i abjomu paniaccia, [v:] Bielaruskaja kniha ǔ kantekscie susvietnaj knižnaj kultury, vyp. 1, č. 1, Minsk 2006.

Liavončykaŭ V. E., Nacyjanaĺny dakumient: padychody da vyznačennia zmiestu i abjomu paniaccia, [v:] Nacyjanaíny dakumient jak abjekt dzejnasci biblijatek Bielarusi, sklad. T. V. Kuźminič, Minsk 2010.

Lelikova N. K., Nauka o knige v Rossii, ili K voprosu o metodologii istoricheskih issledovanij, [v:] Kniga. Issledovaniya i materialy, sb. 86/1, Moskva 2007.

Lelikova N. K., Stanovlenie i razvitie knigovedcheskoj i bibliograficheskoj nauk v Rossii v XIXpervoj treti XX veka, Sankt-Peterburg 2004.

Leončikov V. E., Obshchaya retrospektivnaya bibiografiya knig soyuznyh respublik, „Voprosy bibliotekovedeniya i bibliografovedeniya", 1972, vyp. 1.

Levšun L. V., Ocherki istorii srednevekovoj vostochnoslavyanskoj knizhnosti: evolyuciya tvorcheskih metodov, Minsk 2000.

Migoń K., Istoriya knigovedeniya kak nauka (zamechaniya po materialam pol'skih issledovanij), [v:] Fyodorovskie chteniya, 2011, Moskva 2012.

Migoń K., Istoriografiya nauki o knige: konceptual'nye paradigmy, „Bibliografiya” 2017, № 5.

Migoń K., O neobhodimosti i pol'ze issledovanij po istorii nauki o knige: opyt naukovedcheskogo analiza, „Knygotyra” 2013, t. 60.

Migoń K., Osobennosti vostochnoevropejskogo knigovedeniya i formirovanie nacional'nyh nauchnyh shkol Do vtoroj mirovoj vojny, „Knygotyra” 2007, t. 48.

Motul'skij R. S., Iz istorii v budushchee. Biblioteki Belarusi: v 2 ch., Minsk 2011-2018.

Možejko M. A., Kniga kak kul'turnyj simvol, [v:] Bielaruskaja kniha ǔ kantekscie susvietnaj knižnaj kultury, č. 2, Minsk 2006, vyp. 1.

Možejko M. A., Postmodernistskoe pereosmyslenie fenomena knigi: vnegutenbergovskoe bytie knizhnoj kul'tury, [v:] Bielaruskaja kniha ǔ kantekscie susvietnaj knižnaj kulttury, Minsk 2011, vyp. 3.

Nauchnaya shkola v oblasti pedagogiki „Bibliotekovedenie, bibliografovedenie i knigovedenie”, red. L. I. Dovnar, Minsk 2014.

ROCZNIKI BIBLIOTECZNE

ROK LXIII, 2019

(C) for this edition by CNS 
Navickiene A., Formirovanie nauk o knige i Vil'nyusskij universitet v period pervoj treti XIX veka, [v:] Bielaruskaja kniha ǔ kantekscie susvietnaj knižnaj kultury, Minsk 2017, vyp. 7.

Niedziaržaǔnaja vydavieckaja dzejnasć u Bielarusi: historyja i sučasnasć: materyjaly Mižnar. navuk.-prakt. kanf. (Minsk, 3-4 kastr. 1996 h.), Minsk 1997.

Nemirovskij E. L., Sikorskij Nikolaj Mihajlovich, [v:] Kniga: enciklopediya, Moskva 1999.

Nesterenko Yu. V., Dokumentologicheskij podhod ksootneseniyu ponyatij knigi, dokumenta, izdaniya i proizvedeniya, [v:] Berkovskie chteniya. Knizhnaya kul'tura v kontekste mezhdunarodnyh kontaktov: materialy Mezhdunar. nauch. konf. (Minsk, 25-26 maya 2011 g.), Minsk-Moskva 2011.

Nesterenko Yu., Korrelyaciya ponyatij teksta i proizvedeniya v mezhdisciplinarnom pole, [v:] Bielaruskaja kniha ǔ kantekscie susvietnaj knižnaj kultury, Minsk 2014, vyp. 5.

Nikalaieŭ M. V., Historyja knižnaj kultury Bielarusi: prabliemy i pierspiektyvy dasliedavanniaŭ, [v:] Bielaruskaja kniha ǔ kantekscie susvietnaj knižnaj kultury, č. 1, Minsk 2006, vyp. 1.

Nikalaieǔ M. V., Knižnaja kultura Vialikaha Kniastva Litoǔskaha, Minsk 2009 („Historyja bielaruskaj knihi”, t. 1).

Paviĺč A. A., Stanaǔliennie kamparatyǔnych viedaǔ u knižnaj kultury Belarusì, [v:] Bielaruskaja kniha ǔ kantekscie susvietnaj knižnaj kultury, Minsk 2011, vyp. 3.

Programma lekcij V. Lastovskogo po „Istorii knigi”, Saratov 1936.

Rakovič A. I., Knihaznaǔstva, [v:] Bielaruskaja SSR: karotkaja encyklapiedyja, t. 3, Mìnsk 1980.

Roščyna T. I., Infarmacyjna-biblijahrafičnyja patreby bielaruskaha knigaznaǔstva, [v:] Materialy II Mezhdunarodnogo kongressa "Biblioteka kak fenomen kul'tury", Minsk, 22-23 oktyabrya 2014 g., sost. A. A. Suša, Minsk 2014.

Šabalina M. V., Knigovedenie: opyt regional'nyh izyskanij, Moskva 2006 (Bibliotekar' i vremâ. XXI vek; vyp. 50).

Samojliuk T. A., Knižnaja kuĺtura: sučasnyja tendencyi navukovyh dasliedavanniaŭ, [v:] Bielaruskaja kniha ǔ kantekscie susvietnaj knižnaj kultury, Minsk 2008, vyp. 2.

Sapieha T. A., Belorusskij knigovedcheskij sbornik „Zdabytki” (1995-2013), [v:] Kniga v informacionnom obshchestve: materialy Trinadcatoj Mezhdunarodnoj nauchnoj konferencii po problemam knigovedenija (Moskva, 28-30 aprelia 2014 g.), č. 1, Moskva 2014.

Sapieha T. A., Drukavanaja kniha jak fienomien kultury, [v:] Bielaruskaja kniha ǔ kantekscie susvietnaj knižnaj kultury, č. 2, Minsk 2006, vyp. 1.

Shomrakova I. A., El'yashevich D. A., Otechestvennoe knigovedenie v XXI.: problemy i perspektivy, „Bibliosfera” 2012, № 3.

Suša A., Pieršaja historyja bielaruskaj knihi i jaje stvarennie, [v:] V. Lastoǔski, Historyja bielaruskaj (kryǔskaj) knihi: faksimilinaje vydannie, Minsk 2012.

Suša A., „Knihaznaǔstva”, [v:] Francysk Skaryna: encyklapiedyja, red. U. U. Andryjevič et al., Minsk 2017.

Suša A., Knižnaja kultura, [v:] Francysk Skaryna: encyklapiedyja, red. U. U. Andryjevič et al., Minsk 2017.

Teoretik nauki o knige Aleksandr Viktor Bogatkevich i ego Trud o vseobshchej bibliografii, [v:] Veikalas apie visuotine bibliografija, A. W. Bohatkiewiczius; parengè A. Braziũnienè, A. Navickienè, S. Rankelienè, Vilnius 2004.

Teoretiko-metodologicheskie voprosy bibliotekovedeniya, bibliografovedeniya i knigovedeniya: uchebno-metodicheskij kompleks, V. A. Kasap, V. E. Leončikov, Ž. L. Romanova, Minsk 2017.

Umeckaya E. S., Istoriya knigoizdaniya v Belorussii v pervoj treti XIX veka (1801-1832 gg.), Avtoreferat dissertacii na soiskanie uchenoj stepeni kandidata istoricheskih nauk, Minsk 1977.

Vojtov I. V., Kulikovič V. I., Nauchnyj zhurnal po izdatel'skomu delu i poligrafii kak otrazhenie perspektiv razvitiya otrasli, [v:] Materyjaly mižnarodnaha kanhresa ,,500 hadoǔ bielaruskaha 
knihadrukavannia”. XIII Mižnarodnyja knihaznaǔčyja čytanni (Minsk, 14-15 vierasnia 2017 h.), č. 2, Minsk 201.

Zbralevič L. I., Knihaznaǔstva, [v:] Encyklapiedyja litaratury i mastactva Bielarusi, t. 3, Mìnsk 1986.

Zyuzin A. V., Iz materialov V. U. Lastovskogo, [v:] Bielaruskaja kniha ǔ kantekscie susvietnaj knižnaj kultury, Minsk 2011, vyp. 3.

Žuravskij A. I., Bulyko A. N., 450 let belorusskogo knigopechataniya, „Kniga. Issledovaniya i materialy", sb. 14, Moskva 1967.

\section{LARYSA DOǓNAR}

\section{THE BELARUSIAN BOOK AND BOOK STUDIES: THE EVOLUTION OF CONCEPTS, RESEARCH PARADIGMS AND AN AUTONOMOUS ACADEMIC DISCIPLINE}

\section{Summary}

The aim of the article is to examine the origins, directions of development, methodological assumptions and research categories in Belarusian bibliology as an autonomous academic discipline. An analysis of the most important achievements of books studies in Belarus, the beginnings of which as a science go back to the turn of the nineteenth century, has enabled the author to formulate a number of research hypotheses. Of key importance to the development of Belarusian bibliology were historical studies - they laid the foundations for the modern book science theory, as it was only thanks to research into book history that it became possible to formulate the theory of books studies, the role and place of the book in scholarship, research methods and conceptual apparatus of the discipline. An important role in the development of the methodology of bibliological research in the second half of the twentieth century was played by the studies of the Polish scholar Krzysztof Migoń. A considerable role was also played by the methods developed for the needs of bibliography and library science. The origins and evolution of bibliology in Belarus were and are inextricably linked to the role of the book as a means of disseminating and recording the achievements of the human thought, to the traditions of society's intellectual development, cultural identity of the Belarusian people as well as the general knowledge of book culture. Belarusian bibliology has some significant achievements to its credit, both in historical studies and in book theory and methodology of book studies. As a result, it is possible to speak of the Belarusian book studies school, which is characterised by: 1) the use of interdisciplinary research methodology as well as scholarly interaction with disciplines like philosophy, culture studies, bibliography studies and information studies; 2) development of axiological and phenomenological research; and 3) development of international collaboration in order to make the Belarusian book studies recognisable in international academia. A considerable role was and still is played by bibliological journals, which are a platform for presenting scholarly achievements in the discipline (they include Кнігазнауччыя чыттанні, Кірыла-Мяфодзіеўскія чытанні, Берковские чтения) as well as publication series devoted to the subject.

KEY WORDS: bibliology (book studies), history of bibliology, history of Belarusian bibliology, history of Belarusian books, Belarus 